CHAVES JUNIOR, Airto; SILVA, Luciana Bittencourt Gomes. Garantia da ordem pública como critério de encarceramento cautelar nas câmaras criminais do Tribunal de Justiça do Estado de Santa Catarina: uma análise teórico-empírica. Revista Eletrônica Direito e Política, Programa de Pós-Graduação Stricto Sensu em Ciência Jurídica da UNIVALI, Itajaí, v.15, n.3, 30 quadrimestre de 2020. Disponível em: www.univali.br/direitoepolitica - ISSN 1980-7791

\title{
GARANTIA DA ORDEM PÚBLICA COMO CRITÉRIO DE ENCARCERAMENTO CAUTELAR NAS CÂMARAS CRIMINAIS DO TRIBUNAL DE JUSTIÇA DO ESTADO DE SANTA CATARINA: UMA ANÁLISE TEÓRICO-EMPÍRICA
}

\author{
PUBLIC ORDER AS A JUSTIFICATION FOR PRECAUTIONARY DETENTION IN \\ THE CRIMINAL CHAMBERS OF SANTA CATARINA COURT: A THEORETICAL- \\ EMPIRICAL ANALYSIS
}

\author{
Airto Chaves Junior ${ }^{1}$ \\ Luciana Bittencourt Gomes Silva²
}

\begin{abstract}
RESUMO
O artigo compreende um estudo teórico-empírico da prisão preventiva, realizado por meio da pesquisa de 605 acórdãos lavrados pelas Câmaras Criminais do TJSC no período de 01/07/2019 a 01/07/2020, que examinaram a necessidade da manutenção ou decretação de prisões preventivas em processos relativos ao tráfico de drogas. Os votos foram analisados com o objetivo de aferir os motivos pelos quais se prende preventivamente e verificar se os fundamentos utilizados encontram respaldo teórico e legal que regulam a matéria. Do exame, conclui-se que, em expressiva proporção, as prisões são motivadas por justificativas não cautelares, decorrentes de uma abrangente interpretação dada ao conceito de garantia da ordem pública, possibilitando que os limites da lei e seus requisitos teóricos fossem ultrapassados. Quanto à metodologia, na fase de investigação, denota-se a utilização dos métodos indutivo, o qual é subsidiado pela pesquisa bibliográfica, e empírico, tendo em vista a análise crítica dos precedentes jurisprudenciais.
\end{abstract}

PALAVRAS-CHAVE: Prisão Preventiva; Garantia da Ordem Pública; Processo Penal; Câmaras Criminais do TJSC; Análise teórico-empírica.

\footnotetext{
${ }^{1}$ Mestre e Doutor em Ciência Jurídica pela Universidade do Vale do Itajaí. Doutor em Direito pela Universidade de Alicante, Espanha. Professor de Direito Penal da Escola Superior do Ministério Público do Estado de Santa Catarina. Professor de Direito Penal da Escola da Magistratura do Estado de Santa Catarina. Professor de Direito Penal do Curso de Graduação em Direito e do Programa de Pós-Graduação Stricto Sensu em Ciência Jurídica da Universidade do Vale do ItajaíSC. Advogado criminalista. E-mail: oduno@hotmail.com

2 Mestranda em Ciência Jurídica pela Universidade do Vale do Itajaí. Graduada em Direito pela Universidade Estadual de Ponta Grossa. Especialista em Ciências Penais pela Universidade Anhanguera - UNIDERP. Pós-Graduada pela Escola do Ministério Público do Estado do Paraná. Técnica Judiciária Auxiliar no Tribunal de Justiça do Estado de Santa Catarina. E-mail: luciana_bg@hotmail.com
} 
CHAVES JUNIOR, Airto; SILVA, Luciana Bittencourt Gomes. Garantia da ordem pública como critério de encarceramento cautelar nas câmaras criminais do Tribunal de Justiça do Estado de Santa Catarina: uma análise teórico-empírica. Revista Eletrônica Direito e Política, Programa de Pós-Graduação Stricto Sensu em Ciência Jurídica da UNIVALI, Itajaí, v.15, n.3, $3^{\circ}$ quadrimestre de 2020. Disponível em: www.univali.br/direitoepolitica - ISSN 1980-7791

\section{ABSTRACT}

The article comprises a theoretical-empirical study of precautionary detention through research of 605 court decisions issued by the TJSC Criminal Chambers between $07 / 01 / 2019$ to $07 / 01 / 2020$, that have been analysed the requirement of keeping or decreeing provisional prisons related the narcotic traffic criminal processes. The verdicts where been analyzed to find out the reasons of prisons and if the subject-matter is in accordance with the law. The result concluded that most prisons were been justified by non-precautionary fundamentals, caused by interpretation of the public order exceeding the law and theoretical requirements. Regarding the adopted methodology, it was pointed out that the option was based on the inductive method and the techniques of the referent, the category, the operational concepts, the bibliographic research, and the empirical, due to the analysis of verdicts.

KEYWORDS: Precautionary Detention. Public Order. Criminal Process. TJSC Criminal Chambers. Theoretical-empirical analysis.

\section{INTRODUÇÃo}

A prisão cautelar, antes do trânsito em julgado da sentença, é uma realidade no Brasil e no mundo. Fala-se em abuso na utilização da prisão preventiva: prendese cautelarmente de forma demasiada. Mas, quanto e por quais motivos?

No cenário brasileiro, das 880.199 pessoas atualmente presas, 586.699 $(66,65 \%)$ aguardam um julgamento definitivo, número composto por 394.009 prisões provisórias e 192.690 em execução provisória da pena (CONSELHO NACIONAL DE JUSTIÇA, 2020). Os motivos são os mais diversos, mas em sua grande maioria, manifestamente afastados das funções cautelares do processo penal.

A função da prisão cautelar, no entanto, é processual, não material. Ou seja, não implica em juízo de probabilidade de responsabilidade penal. Por isso, é de cunho excepcional, provisório e proporcional (CPP, art. 282), e desde que necessária ao Processo Penal (CPP, art. 312).

O presente estudo tem por objetivo verificar, no campo empírico, se as Câmaras Criminais do Tribunal de Justiça do Estado de Santa Catarina decretam/mantêm prisões preventivas a partir de fundamentos legais e para fins processuais e, a partir disso, quais são esses fundamentos. 
CHAVES JUNIOR, Airto; SILVA, Luciana Bittencourt Gomes. Garantia da ordem pública como critério de encarceramento cautelar nas câmaras criminais do Tribunal de Justiça do Estado de Santa Catarina: uma análise teórico-empírica. Revista Eletrônica Direito e Política, Programa de Pós-Graduação Stricto Sensu em Ciência Jurídica da UNIVALI, Itajaí, v.15, n.3, 30 quadrimestre de 2020. Disponível em: www.univali.br/direitoepolitica - ISSN 1980-7791

Para tanto, apresentar-se-á pesquisa realizada nos 605 (seiscentos e cinco) acórdãos lavrados pelas 5 Câmaras Criminais do Tribunal de Justiça Catarinense no período de 01/07/2019 a 01/07/2020, que analisaram a necessidade da manutenção/decretação das prisões preventivas dos investigados/acusados, levados a exame no segundo grau de jurisdição e que cuidam de processos relacionados ao crime de tráfico de drogas. Dos precedentes, 99,53\% dos acórdãos em que a prisão foi decretada com fundamento no art. 312 do CPP, foi feita referência à garantia da ordem pública, ou seja, em quase todos eles.

Porém, como a "garantia da ordem pública" é cláusula legal demasiadamente aberta e sem referencial semântico adequado, cumpre investigar as justificativas não cautelares que mais transitaram nos votos dos acórdãos consultados.

Ao final, procurar-se-á responder a seis questões:

a) qual o percentual de prisões preventivas é fundado, isoladamente, na "conveniência da instrução criminal"?

b) qual o percentual de prisões preventivas é fundado, isoladamente, na "garantia da aplicação da lei penal"?

c) qual o percentual de prisões preventivas é fundado, isoladamente, na "garantia da ordem pública"?

d) há fundamentos extralegais (apócrifos) utilizados nos acórdãos para se decretar/manter a prisão preventiva?;

e) quais são os fundamentos que dão sustentação aos acórdãos que decretam/mantém a prisão para garantia da ordem pública?

f) quais os percentuais em que esses fundamentos apócrifos figuram nos acórdãos?

Para compreender a dimensão jurídica do fenômeno da prisão preventiva fundada na garantia da ordem pública, bem como as justificativas a ela alinhadas, o método de pesquisa conjuga análise bibliográfica teórica e verificação de dados oficiais coletados dos precedentes do TJSC. 
CHAVES JUNIOR, Airto; SILVA, Luciana Bittencourt Gomes. Garantia da ordem pública como critério de encarceramento cautelar nas câmaras criminais do Tribunal de Justiça do Estado de Santa Catarina: uma análise teórico-empírica. Revista Eletrônica Direito e Política, Programa de Pós-Graduação Stricto Sensu em Ciência Jurídica da UNIVALI, Itajaí, v.15, n.3, $3^{\circ}$ quadrimestre de 2020. Disponível em: www.univali.br/direitoepolitica - ISSN 1980-7791

\section{A LIBERDADE E SUAS RESTRIÇõES NO ÂMBITO CONSTITUCIONAL}

A liberdade de locomoção, também chamada de liberdade de ir e vir (e ficar), sempre foi uma figura central para o sistema das liberdades fundamentais, de tal sorte que se constitui em presença constante desde a fase inaugural do constitucionalismo ${ }^{3}$. Tanto que José Afonso da Silva ${ }^{4}$ fala de uma "regra constitucional ôntica ${ }^{5}$ da liberdade", a qual figura a estrutura de um ser constitucional.

Ao tratar dos direitos fundamentais, Luigi Ferrajoli ${ }^{6}$ anota que o direito de liberdade integra a classe dos Direitos Humanos compreendidos como os direitos primários de todo ser humano. Trata-se de direito primário da pessoa humana, dentre os quais também se encontram o direito à vida e às liberdades fundamentais, atribuídos pelas normas internacionais a todas as pessoas, independentemente de distinção de status ${ }^{7}$.

No sistema jurídico brasileiro, a partir da leitura do art. 50, caput, da CRFB/88, pode-se verificar que o direito à liberdade assume papel de extrema relevância no rol dos direitos fundamentais, principalmente porque se outorga à liberdade e aos demais direitos ali consignados a garantia de sua inviolabilidade. No bojo da Constituição Federal estão expressamente previstos, dentre outros, os seguintes direitos de liberdade: a) liberdade de locomoção (art. 50, XV); b) liberdade de pensamento (art. 50, IV); c) liberdade de consciência, crença e culto (art. 50, VI); d) liberdade de imprensa (art. 50, IX); e) liberdade de associação (art. 50, XVII).

${ }^{3}$ SARLET, Ingo Wolfgang; MARINONI, Luis Guilherme; MITIDIERO Daniel (Org.). Curso de Direito Constitucional. 6. ed. São Paulo: Saraiva, 2017 (versão digital), p. 564.

${ }^{4}$ SILVA, José Afonso da. Teoria do Conhecimento Constitucional. São Paulo: Malheiros, 2014, p. 363.

5 Observa o autor que "ôntico é adjetivo de origem grega que se refere à estrutura do ser; convenção ôntica é aquela que dá origem a um ser. Então, as regras que oferecem a organização do jogo, que dão estrutura à convenção para que o jogo exista, são regras ônticas, pois definem a própria existência do ser, como as que definem a estrutura, a forma do tabuleiro do jogo de xadrez ou a estrutura, a forma do campo de futebol. Essas regras que exprimem uma necessidade, no sentido de que são necessárias para que o jogo exista, porque criam o espaço em que o jogo deve realizar-se; por isso, como foi dito, são regras ônticas, regras que se expressam mediante o verbo ser. Ver: SILVA, José Afonso da. Teoria do Conhecimento Constitucional. p. 363.

${ }^{6}$ FERRAJOLI, Luigi. Derechos y garantias. 3. ed. Madrid: Trotta, 2002, p. 40.

7 FERRAJOLI, Luigi. Principia iuris: teoria del derecho y de la democracia. Madrid: Trotta, 2007, p. 623. 
CHAVES JUNIOR, Airto; SILVA, Luciana Bittencourt Gomes. Garantia da ordem pública como critério de encarceramento cautelar nas câmaras criminais do Tribunal de Justiça do Estado de Santa Catarina: uma análise teórico-empírica. Revista Eletrônica Direito e Política, Programa de Pós-Graduação Stricto Sensu em Ciência Jurídica da UNIVALI, Itajaí, v.15, n.3, 30 quadrimestre de 2020. Disponível em: www.univali.br/direitoepolitica - ISSN 1980-7791

O dispositivo referente ao Direito de Locomoção tem no inciso XV do art. $5^{\circ}$ da CRFB/88 a seguinte redação: "é livre a locomoção no território nacional em tempo de paz, podendo qualquer pessoa, nos termos da lei, nele entrar, permanecer ou dele sair com seus bens" ${ }^{\prime 8}$. Nesse contexto, a liberdade de locomoção se verifica como figura central para o sistema das liberdades fundamentais ${ }^{9}$, inclusive, assegurando-se a utilização do remédio constitucional do habeas corpus em caso de sua violação, conforme art. 50, LXVIII da CRFB $/ 88^{10}$.

É claro que a liberdade é um direito que não se revela ilimitado ou imune a intervenções restritivas. Porém, ainda que cientes de que a liberdade não é, em princípio, absoluta, mas sim, juridicamente conformada e limitada, não se pode recair no extremo oposto, qual seja, a de entendê-la como uma entidade criada pelo aparelho regulamentador estatal. Na verdade, como Direito Inato que é a liberdade, já que o ser humano, por força de sua própria natureza e dignidade, é livre ${ }^{11}$, deve-se resistir à tese apresentada por Jürgen $S_{c h w a b e}{ }^{12}$, no sentido de que toda e qualquer atuação dos particulares, em última análise, decorra da

\footnotetext{
${ }^{8}$ BRASIL. Constituição (1988). Constituição da República Federativa do Brasil. Brasília, DF: Senado Federal, 1988.

${ }^{9}$ SARLET, Ingo Wolfgang; MARINONI, Luis Guilherme; MITIDIERO Daniel (Org.). Curso de Direito Constitucional. p. 470.

10 "[...] LXVIII - conceder-se-á habeas corpus sempre que alguém sofrer ou se achar ameaçado de sofrer violência ou coação em sua liberdade de locomoção, por ilegalidade ou abuso de poder".

${ }^{11}$ Aliás, neste ponto, importa anotar que a redação do art. 50, XV, da CRFB/88 traz norma de eficácia contida e aplicabilidade imediata por conter a expressão "nos termos da lei", ou seja, estando ausentes leis ulteriores que regulamentem a questão, sua aplicação será imediata, pois dependem de restrições previstas ou dependentes de regulamentação que limite a sua aplicabilidade (SILVA, José Afonso da. Aplicabilidade das Normas Constitucionais. 3. ed. rev. ampl. atual. São Paulo: Malheiros Editores, 1998, p. 83). No mesmo sentido, o art. 50, §10 da CRFB/88 prevê que as normas de direitos fundamentais possuem aplicação imediata, mas, o referido preceito possui exceções, conforme o exemplo citado. Canotilho, neste ponto, anota que "[...] se esta ideia de aplicabilidade direta significa uma normatividade qualificada, nem sempre os direitos, liberdades e garantias dispensam a concretização através de entidades legiferantes. Por outras palavras: a aplicabilidade direta das normas consagradoras de direitos, liberdades e garantias não implica sempre, de forma automática, a transformação destes em direitos subjetivos, concretos e definitivos". (CANOTILHO, J.J. Gomes. Direito Constitucional e Teoria da Constituição. 7. ed. Coimbra: Almeidina, 2003, p. 438). Por fim, vale a assertiva trazida por Robert Alexy: "[...] toda ação (fazer ou não-fazer) é permitida, a não ser que seja proibida por meio de uma norma jurídica formal e materialmente compatível com a Constituição". (ALEXY, Robert. Teoria dos Direitos Fundamentais. Tradução de Vergílio Afonso da Silva. São Paulo: Malheiros, 2008, p. 234).

12 Professor de Direito Público na Universidade de Hamburgo, Alemanha.
} 
CHAVES JUNIOR, Airto; SILVA, Luciana Bittencourt Gomes. Garantia da ordem pública como critério de encarceramento cautelar nas câmaras criminais do Tribunal de Justiça do Estado de Santa Catarina: uma análise teórico-empírica. Revista Eletrônica Direito e Política, Programa de Pós-Graduação Stricto Sensu em Ciência Jurídica da UNIVALI, Itajaí, v.15, n.3, $3^{\circ}$ quadrimestre de 2020. Disponível em: www.univali.br/direitoepolitica - ISSN 1980-7791

autorização ou não-proibição do Estado ${ }^{13}$. Desse modo, permissões nada mais são do que a ausência de limitações ${ }^{14}$. Mas, sendo a liberdade de locomoção passível de limitações, em que circunstâncias ou condições poderia ela ser restringida?

Conforme registra Ingo Sarlet ${ }^{15}$, essas limitações ao direito de liberdade de locomoção decorrem da necessidade de salvaguardar outros direitos fundamentais ou mesmo bens jurídico-constitucionais. Três são, neste ponto, as possibilidades constitucionalmente previstas: a) flagrante delito; b) ordem escrita e fundamentada de autoridade judiciária competente ${ }^{16}$; c) vigência de estado de sítio. ${ }^{17}$ As duas primeiras hipóteses estão previstas no art. 50, LXI, da CRFB $/ 88^{18}$; a terceira encontra previsão do art. 139 , inciso $\mathrm{I}$, do texto constitucional $^{19}$.

O presente estudo se ocupa da análise da restrição da liberdade fundada apenas na segunda possibilidade (letra "b"), mais especificamente no âmbito da prisão preventiva e dos pressupostos que viabilizam a restrição da liberdade pela via desse instrumento.

13 SARLET, Ingo Wolfgang. A constituição concretizada. Porto Alegre: Livraria do Advogado, 2000, p. 136.

${ }^{14}$ Enunciado encontrado em August Thon a partir de Robert Alexy (ALEXY, Robert. Teoria dos Direitos Fundamentais. p. 231).

15 SARLET, Ingo Wolfgang; MARINONI, Luis Guilherme; MITIDIERO Daniel (Org.). Curso de Direito Constitucional. p. 570.

16 Pode-se dar na modalidade de prisão preventiva (CPP, artigos 311 a 316), prisão temporária (Lei 9.760/89), prisão domiciliar (CPP, artigos 317 e 318) e, ainda, prisão civil, hoje, somente permitida em razão do descumprimento da obrigação alimentar (Súmula Vinculante no 25, do STF).

17 Há algumas exceções a essas três regras, também previstas no texto constitucional, a exemplo da restrição da liberdade do militar nos casos de transgressão militar ou crime propriamente militar, definidos em lei (conforme art. 50, LXI, parte final).

$18 \mathrm{CRFB} / 88$, art. 50, LXI, ninguém será preso senão em flagrante delito ou por ordem escrita e fundamentada de autoridade judiciária competente [...].

${ }^{19}$ CRFB/88, Art. 139. Na vigência do estado de sítio decretado com fundamento no art. 137, I, só poderão ser tomadas contra as pessoas as seguintes medidas: I - obrigação de permanência em localidade determinada $[\ldots] "$. 
CHAVES JUNIOR, Airto; SILVA, Luciana Bittencourt Gomes. Garantia da ordem pública como critério de encarceramento cautelar nas câmaras criminais do Tribunal de Justiça do Estado de Santa Catarina: uma análise teórico-empírica. Revista Eletrônica Direito e Política, Programa de Pós-Graduação Stricto Sensu em Ciência Jurídica da UNIVALI, Itajaí, v.15, n.3, 30 quadrimestre de 2020. Disponível em: www.univali.br/direitoepolitica - ISSN 1980-7791

\section{A PRISÃO PREVENTIVA E SUA INSTRUMENTALIDADE QUALIFICADA}

A prisão preventiva é uma modalidade de prisão cautelar ${ }^{20}$ de natureza processual decretada pelo juiz (ou Tribunal), a requerimento do Ministério Público, do querelante ${ }^{21}$ ou do assistente, ou por representação da autoridade policial, sempre que estiverem presentes os requisitos legais e ocorrerem os motivos autorizadores (CPP, artigos 311 e 312), e desde que se revelem inadequadas ou insuficientes as medidas cautelares diversas da prisão (CPP, artigo 319 e $320^{22}$ ). Claus Roxin ${ }^{23}$ define a prisão preventiva como a "privação da liberdade do imputado com o fim de assegurar o processo de conhecimento ou a execução da pena".

Historicamente, a detenção cautelar do investigado/acusado está estritamente alinhada ao princípio da presunção de inocência de forma que, "na medida e nos limites em que a primeira foi sendo cada vez mais admitida e praticada, seguiram-se de perto os desenvolvimentos teóricos e normativos do segundo"24.

$\mathrm{Na}$ qualidade de prisão cautelar, deve ela apresentar devido ajuste às suas finalidades, ao seu objeto. É que, assim como nos demais procedimentos cautelares, a finalidade imediata é assegurar a eficácia do procedimento

\footnotetext{
${ }^{20}$ Basileu Garcia define a prisão cautelar como um "instrumento destinado a atuar em benefício da atividade desenvolvida no processo penal". (GARCIA, Basileu. Comentários ao Código de Processo Penal. Rio de Janeiro: Forense, 1945, p. 7).
}

${ }^{21}$ Ao que parece, a requerimento do querelante, só se admite nos casos de ação penal privada subsidiária da pública (CPP, art. 29), tendo em vista que o art. 313, I, do Código de Processo Penal limita essa modalidade de medida cautelar (prisão preventiva) aos crimes em que a pena máxima cominada é superior a quatro anos.

22 Ao lado da revitalização do instituto da fiança, talvez essa tenha sido a mais importante inovação trazida pela Lei n. 12.403/2011: a previsão de medidas cautelares alternativas à prisão preventiva, colocando à disposição do juiz um leque de possibilidades de instrumentos para cautela do processo penal, diferentes da prisão. Deve-se lembrar que essas medidas diferentes da prisão devem guardar prioridade dentre os instrumentos de cautela, de maneira que a prisão preventiva só deva ser utilizada quando essas medidas diversas se mostrem inadequadas ou insuficientes no caso concreto. Por fim, vale lembrar aquilo que anota Aury Lopes Junior sobre a impossibilidade de restrição de direitos (por meio da prisão ou medidas diversas) fora dos limites legais: o juiz ou tribunal está atrelado ao rol de medidas previsto em lei, não podendo "criar" outras além daquelas previstas no ordenamento. Processo Penal é garantia. Logo, não há espaço para "poderes gerais", pois todo poder é estritamente vinculado a limites e à forma legal. (LOPES JUNIOR, Aury. Direito Processual Penal. 13. ed. São Paulo: Saraiva, 2016 (Versão digital), p. 513).

${ }^{23}$ ROXIN, Claus. Derecho Procesal Penal. Tradução de Gabriela Córdoda y Daniel Pastor. Buenos Aires: Editores del Puerto, 2003, p. 257.

${ }^{24}$ FERRAJOLI, Luigi. Direito e Razão: teoria do garantismo penal. p. 443. 
CHAVES JUNIOR, Airto; SILVA, Luciana Bittencourt Gomes. Garantia da ordem pública como critério de encarceramento cautelar nas câmaras criminais do Tribunal de Justiça do Estado de Santa Catarina: uma análise teórico-empírica. Revista Eletrônica Direito e Política, Programa de Pós-Graduação Stricto Sensu em Ciência Jurídica da UNIVALI, Itajaí, v.15, n.3, 30 quadrimestre de 2020. Disponível em: www.univali.br/direitoepolitica - ISSN 1980-7791

definitivo ${ }^{25}$. A característica básica da prisão preventiva é a "instrumentalidade qualificada": até o trânsito em julgado, ela só pode ser decretada em razão exclusiva de requisitos vinculados ao processo penal. ${ }^{26}$

E isso quer dizer que ela exige fim processual, não material, de cunho excepcional, proporcional e provisório. Não pode ser confundida com qualquer modalidade de "tutela de evidência (instituto previsto no Novo Código de Processo Civil Brasileiro), pois isso é incompatível com o regime de presunção de inocência ${ }^{27}$.

Aliás, é neste sentido que a Corte Interamericana de Direitos Humanos firmou orientação de que do disposto no art. 8.2 da Convenção deriva a obrigação estatal de não restringir a liberdade do detido além dos limites estritamente necessários para assegurar que não impedirá o desenrolar eficiente das investigações e que não prejudicará a ação da justiça, pois a prisão preventiva é uma medida cautelar, não punitiva ${ }^{28}$.

Em razão da gravidade das suas consequências, que afeta mais que o mero direito à liberdade de locomoção da pessoa a ela submetida, mas, notadamente, direitos fundamentais relacionados à integridade física, psíquica e a sua honradez, pode-se afirmar que a prisão preventiva é medida que merece observância em grau máximo dos critérios de necessidade e adequação, bem como dos princípios da razoabilidade, legalidade e proporcionalidade.

\footnotetext{
25 Ao tratar da efetividade do processo, Eugênio Pacelli de Oliveira anota que é necessário preservar o adequado funcionamento de um (o processo) e outra (a jurisdição penal), de maneira a permitir que ambos cumpram as suas importantes missões, tanto como instrumento de garantia do indivíduo quanto de aplicação da lei penal (OLIVEIRA, Eugênio Pacelli de. Curso de Processo Penal. 19. ed. São Paulo: Atlas, 2015, p. 550). É importante, em qualquer dos casos, não confundir os institutos para não subverter as suas finalidades.

${ }^{26}$ E a doutrina parece caminhar neste mesmo sentido. Gustavo Badaró, por exemplo, reforça o caráter instrumental da prisão cautelar ao afirmar que ela não se constitui um fim em si mesma, mas, como qualquer outra medida cautelar, é "um instrumento para atingir a finalidade de assegurar a utilidade e eficácia de um futuro provimento principal". (BADARÓ, Gustavo Henrique. Processo Penal. São Paulo: Revista dos Tribunais, 2015, p. 956); Eugênio Pacelli de Oliveira registra que "a prisão preventiva revela sua cautelaridade na tutela da persecução penal, objetivando impedir que eventuais condutas praticadas pelo alegado autor e/ou por terceiros possam colocar em risco a efetividade do processo". (OLIVEIRA, Eugênio Pacelli de. Curso de Processo Penal. p. 549).
}

27 ROSA, Alexandre Morais da. Guia do Processo Penal conforme a Teoria dos Jogos. 6. ed. Florianópolis: EMais, 2020, p. 449.

${ }^{28}$ STEINER, Sílvia. A convenção americana sobre direitos humanos e sua integração ao processo penal brasileiro. São Paulo: Revista dos Tribunais, 2000, p. 120. 
CHAVES JUNIOR, Airto; SILVA, Luciana Bittencourt Gomes. Garantia da ordem pública como critério de encarceramento cautelar nas câmaras criminais do Tribunal de Justiça do Estado de Santa Catarina: uma análise teórico-empírica. Revista Eletrônica Direito e Política, Programa de Pós-Graduação Stricto Sensu em Ciência Jurídica da UNIVALI, Itajaí, v.15, n.3, $3^{\circ}$ quadrimestre de 2020. Disponível em: www.univali.br/direitoepolitica - ISSN 1980-7791

Para tanto, é imperioso avaliar se a gravidade das consequências geradas pela prisão não supera às dos fins pretendidos, em especial nos casos em que, ao final do processo, seja aplicada uma pena não privativa de liberdade, pois é evidente que "a vantagem produzida pela prisão cautelar não supera as desvantagens advindas da sua utilização no caso de penas concretas não privativas de liberdade"29.

O critério de excepcionalidade decorre da gravidade da medida e, conforme Norberto Avena ${ }^{30}$, deve ser observado tanto sob o ângulo geral - decretação somente nos casos em que a lei ampara e observando o princípio da presunção da inocência - evitando-se, assim, a antecipação da pena, como também numa perspectiva de excepcionalidade restrita, que confere seu caráter de supletividade com relação às demais medidas cautelares previstas na lei.

Conforme o art. 312 do Código de Processo Penal, a prisão preventiva poderá ser decretada para: a) garantia da ordem pública; b) garantia da ordem econômica; c) por conveniência da instrução criminal; e, d) para assegurar a aplicação da lei penal. Tem-se, aqui, o chamado periculum libertatis. Além disso, a parte final do dispositivo traz outro pressuposto condicionante para a decretação da medida: o fumus comissi delicti, que nada mais é do que a prova da existência do crime (materialidade delitiva), indícios suficientes da autoria ou participação e, por fim, perigo gerado pelo estado de liberdade do imputado.

No que se refere ao periculum libertatis, a acepção dos termos que compõem os fundamentos de "aplicação da lei penal" ou por "conveniência da instrução criminal" até podem expressar algum caráter instrumental e de serventia ao processo penal/investigação criminal, muito embora algumas categorias ali empregadas sejam de uma fluidez que perturbam, a exemplo da palavra "conveniência"31.

\footnotetext{
${ }^{29}$ BADARÓ, Gustavo Henrique. Processo Penal. p. 958.

${ }^{30}$ AVENA, Norberto. Processo Penal. Rio de Janeiro: Forense, 2019, p. 910.

${ }^{31}$ Ora, a prisão de alguém não pode se dar por mera conveniência, mas sim de "indispensabilidade demostrada para a instrução criminal. Assim, falar em "conveniência" permite o surgimento de interpretações no sentido de que o acusado ou investigado pode ser preso preventivamente se criar "inconveniências" para o "bom andamento do processo", a exemplo de faltar audiência, residir fora da comarca onde o processo tramita, etc. (FRAGOSO, Christiano Falk. Autoritarismo e Sistema Penal. Rio de Janeiro: Lumen Juris, 2015, p. 330).
} 
CHAVES JUNIOR, Airto; SILVA, Luciana Bittencourt Gomes. Garantia da ordem pública como critério de encarceramento cautelar nas câmaras criminais do Tribunal de Justiça do Estado de Santa Catarina: uma análise teórico-empírica. Revista Eletrônica Direito e Política, Programa de Pós-Graduação Stricto Sensu em Ciência Jurídica da UNIVALI, Itajaí, v.15, n.3, 30 quadrimestre de 2020. Disponível em: www.univali.br/direitoepolitica - ISSN 1980-7791

O mesmo não se pode afirmar, porém, da justificação "para a garantia da ordem pública", eis que, aqui, tem-se cláusula legal demasiadamente aberta, de conceito vago, impreciso, indeterminado e sem referencial semântico adequado $^{32}$. E essa indeterminação acaba por pavimentar um caminho para o abuso na utilização da prisão frente à inobservância concreta de suas causas e condições, sobretudo, porque a ordem pública é alheia a fundamentos processuais.

\section{ORDEM PÚBLICA ${ }^{33}$ : DA CARÊNCIA DE INSTRUMENTALIDADE PROCESSUAL ÀS TENTATIVAS DE COMPENSAÇÃO POR CIRCUNSTÂNCIAS ALHEIAS AO PROCESSO PENAL}

A cautelaridade da prisão só guarda sentido se verificado o devido ajuste às exigências de caráter cautelar com os fins estritamente processuais. Do contrário, trata-se de sequestro estatal. Um sequestro que, desde a sua origem, tem-se revelado verdadeira "pena cautelar" ${ }^{34}$, em flagrante violação ao princípio da presunção de inocência.

\footnotetext{
32 BADARÓ, Gustavo Henrique. Processo Penal. p. 977.

33 Entender o que é "ordem" é tarefa bastante complexa. Isso porque a ordem não é de per si positiva, assim como o caos não é de per si negativo. Há uma mútua dependência entre ambos. Nicola Abbagnano faz referência à noção geral de ordem proposta pelo matemático alemão Gottfried Wilhelm Leibniz. Conforme ele, o que passa por extraordinário é extraordinário somente em relação a alguma ordem particular, estabelecida entre sujeitos porque, quanto à ordem universal, tudo é perfeitamente harmônico. Tanto isso é verdade que no mundo não só nada acontece que esteja absolutamente fora de regra, como também não se saberia sequer imaginar algo semelhante. Desse modo, a ordem consiste simplesmente na possibilidade de expressar com uma regra, ou seja, de maneira geral e constante, uma relação qualquer entre dois ou mais objetos quaisquer. (ABBAGNANO, Nicola. Dicionário de Filosofia. Tradução de Alfredo Bossi. 5. ed. São Paulo: Martins Fontes, 2007, p. 730-731). A noção de ordem, neste sentido, não se distingue da noção de relação constante. Para a categoria "ordem pública", talvez a compreensão seja melhor extraída do sociólogo norte-americano Joel Charon, o qual trata a categoria "ordem social", que para ele, "significa que as ações entre os indivíduos são previsíveis, ordenadas, padronizadas, baseadas em regras. Cada ator é, em certa medida, governado pela sociedade. Existindo a ordem, os atores não agem de modo como desejam. A ação é governada por expectativas mútuas e um contrato governa o relacionamento". (CHARON, Joel. Sociologia. Tradução de Laura Teixeira Motta. São Paulo, 1999, p. 148).

34 Materialmente, é isso que se tem. A prisão preventiva é pena cautelar porque, por precaução, "o poder punitivo é exercido condenando-se materialmente esses investigados/acusados a uma medida e revisando-se com grande parcimônia essas condenações, num processo que pode se arrastar anos a fio, com o intuito de verificar se corresponde a uma pena formal". A revogação da prisão preventiva, no caso, "representa uma absolvição, pois corresponde a quase todos os seus efeitos" (ZAFFARONI, Eugenio Raúl. O inimigo no direito penal. Tradução de Sérgio Lamarão. 3. ed. Rio de Janeiro: Revan, 2019, p. 70).
} 
CHAVES JUNIOR, Airto; SILVA, Luciana Bittencourt Gomes. Garantia da ordem pública como critério de encarceramento cautelar nas câmaras criminais do Tribunal de Justiça do Estado de Santa Catarina: uma análise teórico-empírica. Revista Eletrônica Direito e Política, Programa de Pós-Graduação Stricto Sensu em Ciência Jurídica da UNIVALI, Itajaí, v.15, n.3, 30 quadrimestre de 2020. Disponível em: www.univali.br/direitoepolitica - ISSN 1980-7791

Com o advento dos regimes fascista e nazista na Europa da década de 1930 do século passado, a presunção de inocência entrou em crise, momento em que a prisão preventiva passou a ser utilizada como "medida de segurança processual", "necessária para a defesa social" e, ainda, indispensável sempre que o delito tivesse desencadeado "grave clamor público"35. É neste período em que o nazifascismo busca uma justificativa para se prender indesejáveis sem motivo concreto que a prisão preventiva assume a fisionomia de medida de prevenção. ${ }^{36}$ $\mathrm{Na}$ época, passa-se a sustentar que "a missão do sistema judicial é contribuir para a preservação e a segurança do povo diante de certos elementos que, como antissociais, lutam para se esquivar de deveres comuns ou que pecam contra esses interesses comuns" ${ }^{\prime 37}$. Aliás, outra íntima semelhança da prisão para garantia da ordem com o regime nazista pode ser verificada no rompimento com o princípio da legalidade. É bastante tranquilo no plano doutrinário ${ }^{38}$ que este princípio também se aplica às medidas cautelares no Processo Penal, mormente em tema de prisão preventiva, pois inexistem medidas cautelares atípicas. Por isso, as medidas cautelares processuais penais são somente aquelas previstas em lei e nas hipóteses estritas que a lei as autoriza, pois é ela (a lei) o limite (do Poder Punitivo do Estado para com o sujeito) e a garantia (do sujeito para com o Estado). Por isso é que se pode sustentar com razoável segurança que a indeterminação e o consequente casuísmo incorporado na expressão "garantia da ordem pública" se afasta do princípio liberal de "nenhum crime sem lei", ao passo que suscita uma odiosa aproximação do slogan "nenhum crime sem punição". Conforme se verifica na história, o Processo Penal, na medida em que

\footnotetext{
${ }^{35}$ FERRAJOLI, Luigi. Derechos y garantias. 3. ed. Madrid: Trotta, 2002, p. 444.

36 Antes disso, porém, a expressão "ordem pública" já aparecia no art. 48 da Constituição de Weimar. Giorgio Agamben conta que a história desse dispositivo está tão estreitamente entrelaçada com a história da Alemanha entre as duas guerras que não é possível compreender a ascensão de Hitler ao poder sem uma análise preliminar dos usos e abusos deste artigo nos anos que vão de 1919 a 1933. O texto do art. 48 dizia o seguinte: "Se a segurança e a ordem pública no Reich alemão forem seriamente (erheblich) perturbadas ou ameaçadas, o presidente do Reich pode tomar as medidas necessárias para restabelecer a segurança e a ordem pública, eventualmente com a ajuda das forças armadas. Com este fim pode suspender no todo ou em parte os direitos fundamentais (Grundrechte) estabelecidos nos artigos $114 .{ }^{\circ}, 115.0^{\circ}, 117.0,118 .{ }^{\circ}, 123.0^{\circ}, 124.0^{\circ} \mathrm{e}$ 153.0" (AGAMBEN, Giorgio. Estado de excepção. Tradução de Miguel Freitas da Costa. Lisboa/Porto: Edições 70. São Paulo: Boitempo, 2010, p. 30).

37 GELLATELY, Robert. Apoiando Hitler: consentimento e coerção na Alemanha nazista. Tradução de Vitor Paolozzi. Rio de Janeiro: Editora Record, 2011, p. 74-75.
}

${ }^{38}$ ROSA, Alexandre Morais da. Guia do Processo Penal conforme a Teoria dos Jogos. p. 421. 
CHAVES JUNIOR, Airto; SILVA, Luciana Bittencourt Gomes. Garantia da ordem pública como critério de encarceramento cautelar nas câmaras criminais do Tribunal de Justiça do Estado de Santa Catarina: uma análise teórico-empírica. Revista Eletrônica Direito e Política, Programa de Pós-Graduação Stricto Sensu em Ciência Jurídica da UNIVALI, Itajaí, v.15, n.3, $3^{\circ}$ quadrimestre de 2020. Disponível em: www.univali.br/direitoepolitica - ISSN 1980-7791

regula os embates entre a autoridade pública e o particular em torno do exercício do poder punitivo, é um fértil campo para manifestações autoritárias ${ }^{39}$.

No Brasil, os requisitos previstos em lei figuram num plano meramente retórico. Nos tribunais, a utilização da prisão cautelar para garantir a ordem pública tem sido deliberadamente aplicada às mais diversas situações, deixando nu o autoritarismo intrínseco do sistema. Conforme se mostrará na sequência, pouco importa se há referente processual de risco de fuga do investigado/acusado ou, ainda, interferência na produção de informações ou provas que possam interessar à investigação ou à futura e eventual ação penal, o que confirma aquilo que Zaffaroni ${ }^{40}$ vem registrando desde a década passada: "o poder punitivo se opera na América Latina por meio das contenções cautelares".

De acordo com os dados do Levantamento Nacional de Informações Penitenciárias - INFOPEN ${ }^{41}$, referentes ao período de julho a dezembro de 2019, constata-se que $29,75 \%{ }^{42}$ do total de 748.009 pessoas presas, aguardavam julgamento dentro do Sistema Prisional Brasileiro (são investigados ou processados não condenados)..$^{43}$

E esse número de prisões cautelares é confirmado pelos índices apresentados pelo Banco Nacional de Monitoramento de Prisões - $\mathrm{CNJ}^{44}$, que, com cifras mais fidedignas à realidade, informam que das 880.199 pessoas atualmente presas ${ }^{45}$,

\footnotetext{
39 FRAGOSO, Christiano Falk. Autoritarismo e Sistema Penal. p. 327.

${ }^{40}$ ZAFFARONI, Eugenio Raúl. O inimigo no direito penal. p. 70.

${ }^{41}$ Sistema de informações estatísticas do sistema penitenciário brasileiro atualizado pelos gestores dos estabelecimentos desde 2004, cuja metodologia fora reformulada em 2020, passando a ser apresentado no formato de painéis dinâmicos online que sintetizam os dados sobre os estabelecimentos penais e a população prisional.
}

42 O que corresponde a 222.558 pessoas presas.

43 BRASIL. Ministério da Justiça. Levantamento Nacional de Informações Penitenciárias 2019 -INFOPEN. Brasília, 2019. Disponível em: https://app.powerbi.com/view?r=eyJrIjoiZWI2MmJmMzYtODA2MC00YmZiLWI4M2ItNDU2ZmIyZjFj ZGQ0IiwidCI6ImViMDkwNDIwLTQ0NGMtNDNmNy05MWYyLTRIOGRhNmJmZThIMSJ9. Acesso em: 20 jul 2020.

${ }^{44}$ Banco de dados, integrado nacionalmente e alimentado, de forma dinâmica e em tempo real, pelos Tribunais de Justiça e Tribunais Regionais Federais, implantado pelo Conselho Nacional de Justiça desde 2016 como instrumento de gestão de processos, direcionado aos juízes e ao cidadão, como forma de cumprimento às providências determinadas pelo Supremo Tribunal Federal na ADPF 347 e RE 641.320/RS.

${ }^{45}$ Incluídas, nessa contagem, as 1.359 prisões civis. 
CHAVES JUNIOR, Airto; SILVA, Luciana Bittencourt Gomes. Garantia da ordem pública como critério de encarceramento cautelar nas câmaras criminais do Tribunal de Justiça do Estado de Santa Catarina: uma análise teórico-empírica. Revista Eletrônica Direito e Política, Programa de Pós-Graduação Stricto Sensu em Ciência Jurídica da UNIVALI, Itajaí, v.15, n.3, 30 quadrimestre de 2020. Disponível em: www.univali.br/direitoepolitica - ISSN 1980-7791

$586.699(66,65 \%)$ aguardam um julgamento definitivo, número composto por 394.009 prisões provisórias e 192.690 em execução provisória da pena. ${ }^{46}$

Do ponto de vista formal, isso constitui uma inversão do Sistema Penal. Porém, os estudos no âmbito da criminologia ${ }^{47}$ mostram que isso revela um poder punitivo que há muitas décadas preferiu operar mediante a prisão preventiva ou por medida de contenção provisória transformada definitivamente na prática. Dito de outro modo: é bastante evidente que o poder punitivo brasileiro atua sob a forma das restrições da liberdade mediante o instrumento da prisão preventiva.

\section{ANÁLISE TEÓRICO-EMPÍRICA DAS DIVERSAS INTERPRETAÇÕES DA "GARANTIA DA ORDEM PÚBLICA" NA JURISPRUDÊNCIA CRIMINAL CATARINENSE}

O alto percentual de encarceramento cautelar no Estado de Santa Catarina não destoa dos números gerais do restante do país, correspondendo, até dezembro de 2019, a praticamente um quarto de toda a população carcerária dessa Unidade Federativa $(24,23 \%)^{48}$. Contudo, o cerne da problemática não reside apenas nos números daí extraídos, mas na persistência e aparente normalização dessa situação extrema, oportunizada e avalizada, cada vez mais, pelo Poder Judiciário. Dada a fluidez e ausência de densidade normativa do suposto conceito de ordem pública, a categoria é moldada a partir de outros critérios (não previstos em lei), outras interpretações (de mera conveniência). E isso cria um sistema paralelo de encarceramento fundamentado em critérios atípicos, arbitrários e casuísticos.

\footnotetext{
${ }^{46}$ CONSELHO NACIONAL DE JUSTIÇA. Banco Nacional de Monitoramento de Prisões - BNMP. Brasília, 2020. Disponível em: https://portalbnmp.cnj.jus.br/\#/estatisticas. Acesso em: 27 jul 2020.

47 ZAFFARONI, Eugenio Raúl. O inimigo no direito penal. p. 7.

48 BRASIL. Ministério da Justiça. Levantamento Nacional de Informações Penitenciárias 2019-INFOPEN. Brasília, 2019. Disponível https://app.powerbi.com/view?r=eyJrIjoiZWI2MmJmMzYtODA2MC00YmZiLWI4M2ItNDU2ZmIyZjFj ZGQ0IiwidCI6ImViMDkwNDIwLTQ0NGMtNDNmNy05MWYyLTRiOGRhNmJmZThIMSJ9. Acesso em: 20 jul 2020.
} 
CHAVES JUNIOR, Airto; SILVA, Luciana Bittencourt Gomes. Garantia da ordem pública como critério de encarceramento cautelar nas câmaras criminais do Tribunal de Justiça do Estado de Santa Catarina: uma análise teórico-empírica. Revista Eletrônica Direito e Política, Programa de Pós-Graduação Stricto Sensu em Ciência Jurídica da UNIVALI, Itajaí, v.15, n.3, $3^{\circ}$ quadrimestre de 2020. Disponível em: www.univali.br/direitoepolitica - ISSN 1980-7791

A presente pesquisa analisou 605 (seiscentos e cinco) acórdãos ${ }^{49}$ lavrados pelas 5 Câmaras Criminais do Tribunal Catarinense no período compreendido entre 01/07/2019 e 01/07/2020, que decretaram ou mantiveram as prisões preventivas dos investigados/acusados levados a exame do segundo grau de jurisdição por meio do ajuizamento de Habeas Corpus, interposição de Apelação Criminal e de Recurso em Sentido $\operatorname{Estrito~}^{50}$ (Gráfico 1):

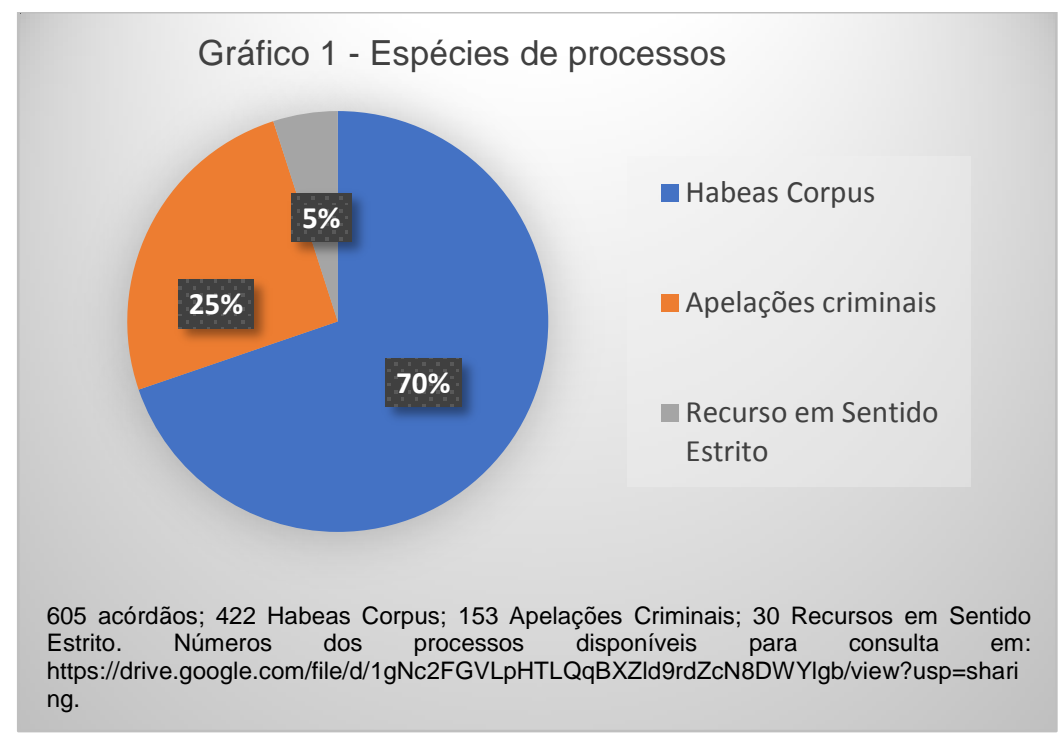

Do exame realizado nesses precedentes, verificou-se que em $80 \%$ dos casos (512 casos) em que se decretou ou se manteve a prisão preventiva, um dos fundamentos incorporados à decisão foi o da garantia da ordem pública (Gráfico 2):

\footnotetext{
49 Relação dos processos consultados disponível para consulta em: https://drive.google.com/file/d/1gNc2FGVLpHTLQqBXZId9rdZcN8DWYlgb/view?usp=sharing.

${ }^{50}$ Importa afirmar que todos os Acórdãos pesquisados têm como objeto de apuração o crime de tráfico de drogas, sobretudo, em razão da sua alta incidência nos índices totais de encarceramento que, atualmente no Brasil, alcança o número de 200.583 presos por crimes desta natureza, o que constitui o motivo de $27,52 \%$ das prisões no Estado de Santa Catarina (BRASIL. Ministério da Justiça. Levantamento Nacional de Informações Penitenciárias 2019- INFOPEN. Brasília, $2019 . \quad$ Disponível em: https://app.powerbi.com/view?r=eyJrIjoiZWI2MmJmMzYtODA2MC00YmZiLWI4M2ItNDU2ZmIyZjFj ZGQ0IiwidCI6ImViMDkwNDIwLTQONGMtNDNmNy05MWYyLTRiOGRhNmJmZThIMSJ9. Acesso em: 20 jul 2020).
} 
CHAVES JUNIOR, Airto; SILVA, Luciana Bittencourt Gomes. Garantia da ordem pública como critério de encarceramento cautelar nas câmaras criminais do Tribunal de Justiça do Estado de Santa Catarina: uma análise teórico-empírica. Revista Eletrônica Direito e Política, Programa de Pós-Graduação Stricto Sensu em Ciência Jurídica da UNIVALI, Itajaí, v.15, n.3, $3^{\circ}$ quadrimestre de 2020. Disponível em: www.univali.br/direitoepolitica - ISSN 1980-7791

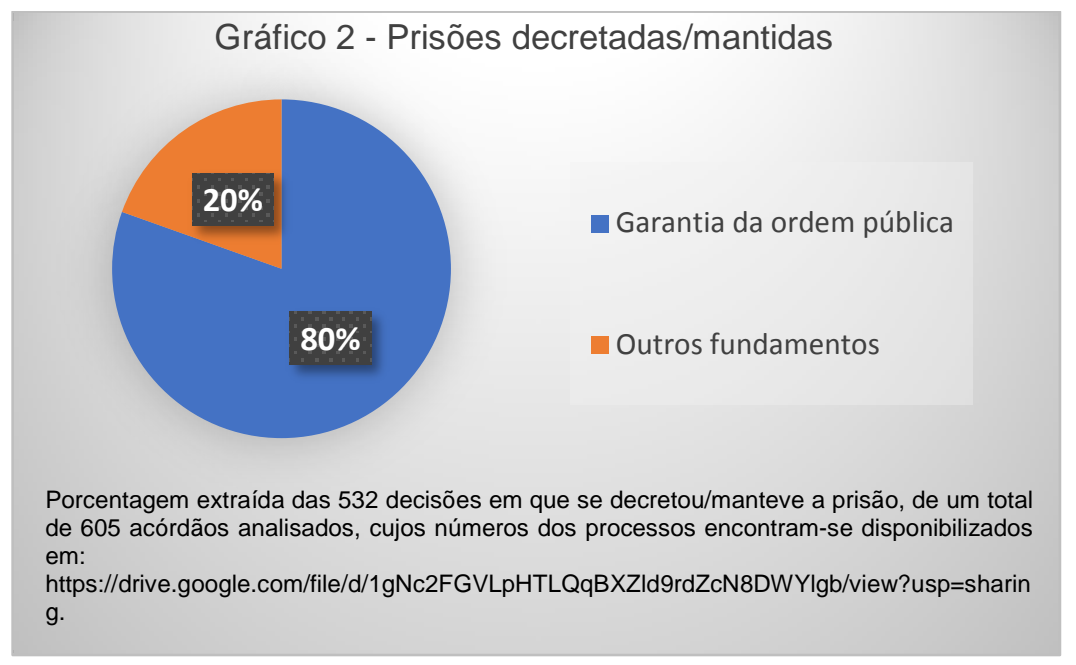

Considerando as decisões em que se conjugaram os demais fundamentos do art. 312 do Código de Processo Penal, observa-se um expressivo aumento na porcentagem: agora, são $99,53 \%$ os acórdãos em que foi feita referência à garantia da ordem pública (Gráfico 3):

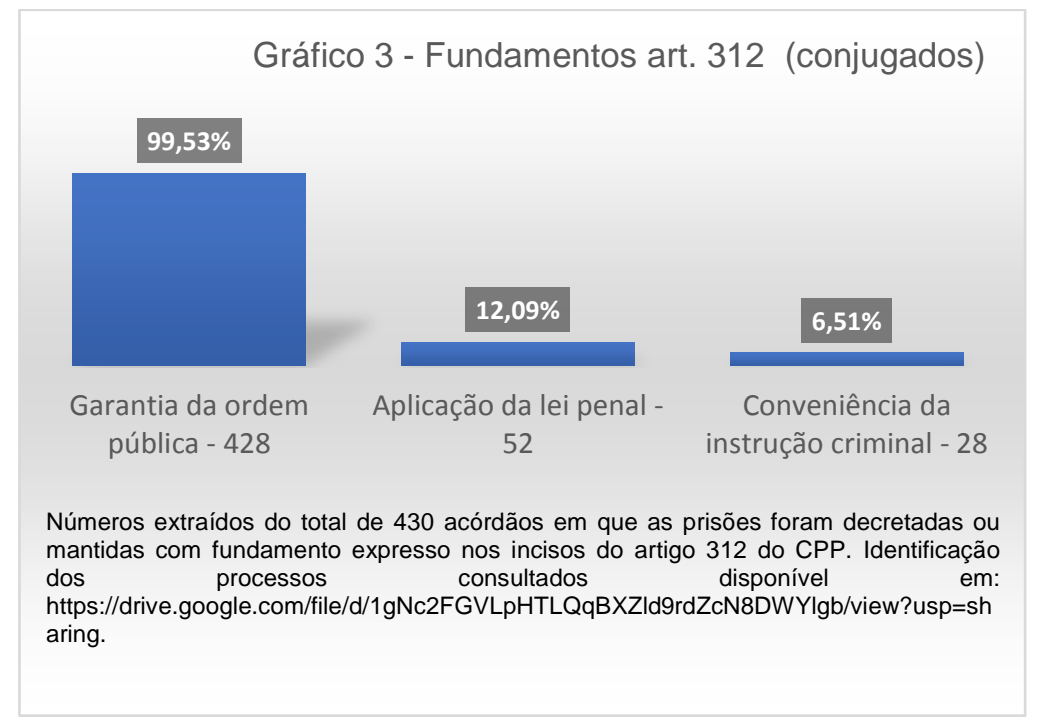

Outra constatação extraída dos julgados é que, mesmo quando se conclui que a prisão não é mais necessária nem conveniente para a instrução criminal ou para assegurar a aplicação da lei penal, o cárcere cautelar subsiste para a garantia da ordem pública. Nestes casos, a prisão preventiva foi mantida para garantia da ordem pública em 374 dos 430 acórdãos (86,97\%), incluindo-se, aqui, situações em que a prisão havia sido decretada originariamente, com base naqueles dois fundamentos (conveniência da instrução criminal e asseguramento da aplicação da lei penal) do art. 312 do Código de Processo Penal (Gráfico 4): 
CHAVES JUNIOR, Airto; SILVA, Luciana Bittencourt Gomes. Garantia da ordem pública como critério de encarceramento cautelar nas câmaras criminais do Tribunal de Justiça do Estado de Santa Catarina: uma análise teórico-empírica. Revista Eletrônica Direito e Política, Programa de Pós-Graduação Stricto Sensu em Ciência Jurídica da UNIVALI, Itajaí, v.15, n.3, 30 quadrimestre de 2020. Disponível em: www.univali.br/direitoepolitica - ISSN 1980-7791

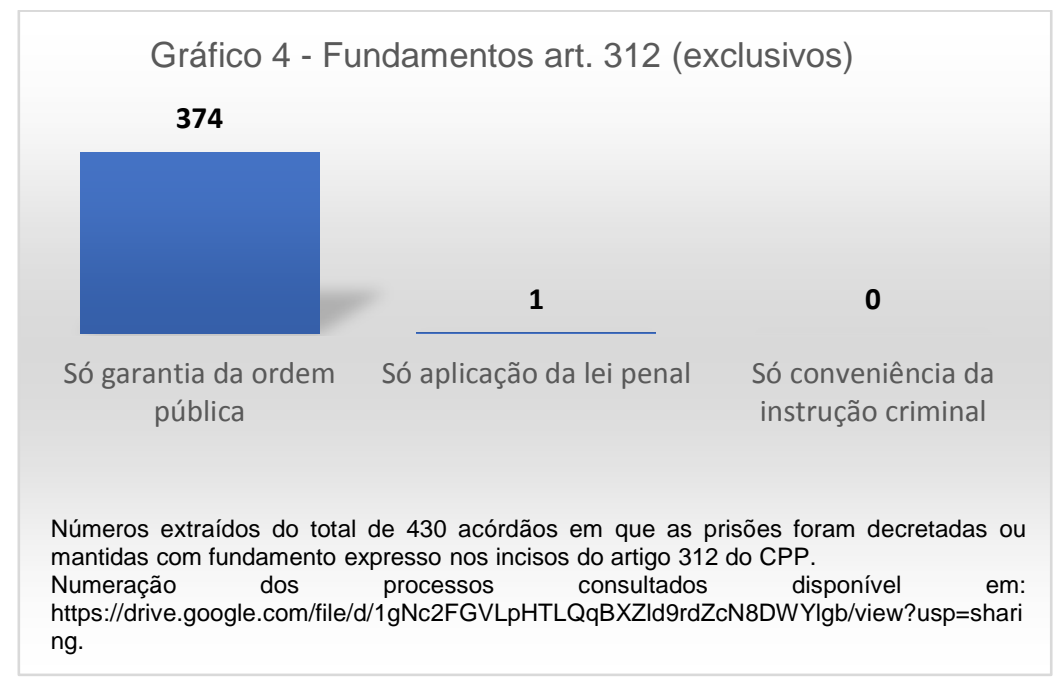

Na sequência, abordar-se-ão as cinco justificativas não cautelares que mais transitaram nos votos dos acórdãos dos 605 precedentes consultados e que decretam ou mantêm a prisão preventiva sob o fundamento da garantia da ordem pública nas Câmaras Criminais do Tribunal de Justiça do Estado de Santa Catarina, quais sejam: a) intranquilidade coletiva no seio da comunidade; b) características ligadas ao sujeito (periculosidade, por exemplo); c) merecimento; d) suposta futura reiteração da conduta delitiva; e, e) assegurar a credibilidade da justiça.

\subsection{Prisão como garantia da ordem pública em virtude de suposta intranquilidade coletiva no seio da comunidade}

Essa primeira interpretação que se opera à ordem pública é abarcada por parte da doutrina brasileira, a exemplo de Eugênio Pacelli de Oliveira. Conforme o autor, a ordem pública só poderia fundamentar a prisão preventiva na hipótese de se constatar uma situação de comprovada intranquilidade coletiva no seio da comunidade ${ }^{51}$. Guilherme de Souza Nucci ${ }^{52}$ também reconhece que a repercussão social gerada pela prática do delito pode fundamentar a prisão preventiva, mas desde que cumulada com outras duas circunstâncias (também sem relação com o processo): a gravidade do crime e a periculosidade do agente.

\footnotetext{
${ }^{51}$ OLIVeirA, Eugênio Pacelli de. Curso de Processo Penal. p. 559.

${ }^{52}$ NUCCI, Guilherme de Souza. Manual de processo penal e execução penal. 5. ed. São Paulo: Revista dos Tribunais, 2008, p. 547.
} 
CHAVES JUNIOR, Airto; SILVA, Luciana Bittencourt Gomes. Garantia da ordem pública como critério de encarceramento cautelar nas câmaras criminais do Tribunal de Justiça do Estado de Santa Catarina: uma análise teórico-empírica. Revista Eletrônica Direito e Política, Programa de Pós-Graduação Stricto Sensu em Ciência Jurídica da UNIVALI, Itajaí, v.15, n.3, 30 quadrimestre de 2020. Disponível em: www.univali.br/direitoepolitica - ISSN 1980-7791

Dos acórdãos pesquisados, esse fundamento foi diagnosticado em 114 julgados. Para tanto, o TJSC se utilizou de assertivas como "a liberdade causa temor", "proteção da coletividade" ou "prisão para acautelar o meio social", dentre outras de equivalente teor. ${ }^{53}$

Além disso, a intranquilidade social também respaldou a prisão em 102 casos analisados, nos quais, valendo-se da regra geral de que o delito de tráfico "fomenta a prática de outros crimes", a prisão foi imposta como medida necessária para afastar o perigo do crime da coletividade. ${ }^{54}$

Mas, da leitura dos precedentes, as perguntas que surgem são quase automáticas: o que seria "intranquilidade coletiva"? Essa coletividade não poderia ser manipulada pelos meios de mídia ou instruída maliciosamente por (des) informações das redes sociais? O fato é que não se pode ignorar que essa "intranquilidade coletiva", mencionada nos acórdãos e por parte da doutrina é muito bem manipulada pelos meios de mídia. Há crimes que geram intranquilidade coletiva porque são alvos de cobertura jornalística com intensidade tão parcial e implacável que a liberdade do investigado passa a ser avaliada como sinal de perigo para aquela leitura que se tem de sociedade. Hoje,

\footnotetext{
53 Veja-se, a título exemplificativo: "No que atine à imperiosidade da clausura cautelar, as circunstâncias que permeiam a conjuntura sob exame - [...] - denotam que a sua liberdade, neste momento, representa nítido risco à paz social, sendo certo que a proteção da coletividade e a credibilidade da Justiça são elementos que também devem ser considerados. [...] Frisa-se que a repercussão resultante da narcotraficância, quer no âmbito da saúde pública, quer na esfera da criminalidade, evidencia concreta ameaça à sociedade, tendo em vista que sabidamente é precursora de diversos outros injustos, os quais muitas vezes são cometidos com violência ou grave ameaça à pessoa, de forma a tornar imperiosa a conservação da clausura." (HC 402597112.2019.8.24.0000); Outro: "Demais disso, a criminalidade advinda da comercialização e da distribuição de drogas causa efetivo desassossego social em prejuízo da ordem pública, já que fomenta a prática de diversos delitos, principalmente os de cunho patrimonial". (HC 402338417.2019.8.24.0000). (Sem grifos no original).

54 "Por fim, consigna-se que o delito de tráfico ilícito de entorpecentes é crime grave e fomentador de outros delitos." (HC 4019332-75.2019.8.24.0000). "Afora isso, o tráfico ilícito de entorpecentes é delito equiparado a hediondo, que gera relevante perturbação na sociedade ao disseminar infelicidade nos lares e fomentar a prática de outros delitos, o que caracteriza severo prejuízo à ordem pública." (HC 4018764-59.2019.8.24.0000); "Ora, é amplamente cediço que a distribuição da droga instala a infelicidade nos lares e provoca a desgraça de jovens e adultos, em manifesto ato contra a sociedade organizada, além de fomentar a prática de crimes outros cuja razão maior é a obtenção de lucros fáceis com a desgraça de muitos, característica especial do delito de tráfico, que traz consequências nefastas àquela, razões pelas quais se faz mister a prisão do paciente." (HC 4021704-94.2019.8.24.0000); "É cediço que o tráfico de entorpecentes, fomentador da crescente onda de criminalidade violenta, é delito de concreta gravidade e possui repercussão social com reflexos negativos perante a sociedade, fatos estes que devem ser sopesados no conceito de garantia da ordem pública." (RESE 0008552-75.2019.8.24.0023). (Sem grifos no original).
} 
CHAVES JUNIOR, Airto; SILVA, Luciana Bittencourt Gomes. Garantia da ordem pública como critério de encarceramento cautelar nas câmaras criminais do Tribunal de Justiça do Estado de Santa Catarina: uma análise teórico-empírica. Revista Eletrônica Direito e Política, Programa de Pós-Graduação Stricto Sensu em Ciência Jurídica da UNIVALI, Itajaí, v.15, n.3, $3^{\circ}$ quadrimestre de 2020. Disponível em: www.univali.br/direitoepolitica - ISSN 1980-7791

aquilo que as pessoas conhecem (em sua forma e extensão) é trazido a elas, principalmente, pela mídia e pelas redes sociais, as quais funcionam como verdadeiro instrumento de mediação do conhecimento ${ }^{55}$. Leve-se em conta, ainda, o fenômeno mais recente das fake news, que comportam o incomensurável poder de destruir a imagem e reputação de pessoas em poucas horas. Há situações em que, por mais absurda que a informação (ou opinião divulgada) se mostre, possui enormes chances de ser incorporada como realidade no processo de cognição do ouvinte, leitor ou telespectador. Enfim, prende-se a partir de suspeitas não provadas.

Dito isso, conforme se observa, muito facilmente a "tranquilidade coletiva" pode ser abalada e, muitas das vezes, por fatores alheios à causa. Tem-se, portanto, um "corpo estranho" nos sistemas de pressupostos de decretação da prisão preventiva porque, definitivamente, não se trata de qualquer condição de cautelaridade do Processo Penal.

\subsection{Prisão como garantia da ordem pública em razão da suposta periculosidade social do investigado/acusado}

A segunda justificativa (ainda que simulada no âmbito da fundamentação judicial) é a correlação com critérios ligados à própria prática do delito ou referentes às características do sujeito. Em 99 acórdãos, a prisão preventiva foi decretada ou mantida com fundamento na suposta gravidade da conduta, deduzida a partir de atos relativos à própria execução do delito de tráfico ou às características do sujeito, notadamente à sua periculosidade. ${ }^{56}$

Em 20\% dos casos (106 acórdãos em que a prisão foi mantida ou decretada) constatou-se a referência a expressões relativas à própria adequação típica para

${ }^{55}$ CHAVES JUNIOR, Airto; OLDONI, Fabiano. Para que(m) serve o Direito Penal? Uma análise criminológica dos segmentos de controle social. Rio de Janeiro: Lumen Juris, 2014, p. 70.

56 Veja-se, por exemplo: "Isso porque a hipótese de resguardar a ordem pública fundamentou-se na necessidade de se acautelar o meio social em razão da periculosidade do agente, especialmente em virtude da gravidade concreta do delito perpetrado, o que se verificou a partir das circunstâncias da apreensão do entorpecente - paciente flagrado realizando suposta transação de drogas e que tentou dispensar assim que viu a guarnição da polícia." (HC 403013180.2019.8.24.0000); "Logo, todos os elementos coincidem de modo a evidenciar a periculosidade do agente e autorizar a prisão processual, a bem da garantia da ordem pública, desponta a correção da decisão hostilizada." (HC 4028993-78.2019.8.24.0000). (Sem grifos no original). 
CHAVES JUNIOR, Airto; SILVA, Luciana Bittencourt Gomes. Garantia da ordem pública como critério de encarceramento cautelar nas câmaras criminais do Tribunal de Justiça do Estado de Santa Catarina: uma análise teórico-empírica. Revista Eletrônica Direito e Política, Programa de Pós-Graduação Stricto Sensu em Ciência Jurídica da UNIVALI, Itajaí, v.15, n.3, 30 quadrimestre de 2020. Disponível em: www.univali.br/direitoepolitica - ISSN 1980-7791

fundamentar o periculum libertatis, tais como "foram localizados petrechos comumente utilizados na atividade ilícita", "há notícia de que o paciente se dedicava ao tráfico de drogas, como entregador", "há fortes indícios de que a droga era destinada à venda", ou fazendo-se a simples alusão a "indícios de que pratica a narcotraficância". Isso leva à conclusão de que o fato de realizar os verbos que compõem o tipo objetivo do tipo penal de tráfico de drogas pode automaticamente ensejar a decretação de uma prisão cautelar. ${ }^{57}$

Com base nessas asserções, é possível verificar a constante confusão entre os requisitos materiais para a configuração do delito e as questões processuais referentes à prisão cautelar e a liberdade. Os mesmos fatos observados para apuração da ocorrência do crime de tráfico são utilizados como pressuposto, como requisito e como fundamento da prisão preventiva, evidenciando que, ao fim do processo, invariavelmente, as mesmas evidências que sustentaram a prisão fundamentarão a provável condenação, misturando-se questões processuais com materiais.

Semelhante inadequação foi verificada quanto à definição da finalidade da prisão e do próprio processo, manifestada em decisões em que se afirmou que "uma das funções do processo é a proteção da sociedade" (ACr. 000109645.2018.8.24.0044; ACr. 0001417-05.2017.8.24.0048; ACr. 000352692.2015.8.24.0005; ACr. 0007477-53.2019.8.24.0038; 000531737.2018.8.24.0023), demonstrando um (des)entendimento de imanência entre institutos materiais e processuais penais.

\footnotetext{
57 "No que tange ao periculum libertatis, as peculiaridades do flagrante, principalmente a quantidade de tóxico e petrechos relacionados ao ramo do narcotráfico apreendidos, aliado ao histórico criminal desabonador do paciente (certidão de p. 25/28), são aspectos suficientes para manter a prisão decretada como garantia da ordem pública e obstar a aplicabilidade de medidas diversas do encarceramento." (HC 4024892-95.2019.8.24.0000); "No caso concreto, tem-se que foram apontados elementos concretos de denotar a necessidade da segregação cautelar para a garantia da ordem pública. Isso porque a autoridade impetrada fez menção expressa à quantidade de material entorpecente apreendida (cerca de trezentos e setenta e cinco gramas de maconha), além de ressaltar que foram localizados petrechos comumente utilizados na atividade ilícita (balança de precisão, faca com resquícios da droga em questão e filme de PVC), bem como as notícias de que o paciente se dedicava ao tráfico de drogas, como entregador[...]" (HC 403001222.2019.8.24.0000); "[...] a hipótese de resguardar a ordem pública fundamentou-se na necessidade de se acautelar o meio social em razão da periculosidade do agente, especialmente em virtude da gravidade concreta do delito perpetrado, o que se verificou a partir das circunstâncias da apreensão do entorpecente - paciente flagrado realizando suposta transação de drogas e que tentou dispensar assim que viu a guarnição da polícia." (HC 403013180.2019.8.24.0000). (Sem grifos no original).
} 
CHAVES JUNIOR, Airto; SILVA, Luciana Bittencourt Gomes. Garantia da ordem pública como critério de encarceramento cautelar nas câmaras criminais do Tribunal de Justiça do Estado de Santa Catarina: uma análise teórico-empírica. Revista Eletrônica Direito e Política, Programa de Pós-Graduação Stricto Sensu em Ciência Jurídica da UNIVALI, Itajaí, v.15, n.3, 30 quadrimestre de 2020. Disponível em: www.univali.br/direitoepolitica - ISSN 1980-7791

Essa problemática justificação da prisão, ligada a critérios materiais ou pessoais, acaba por gerar a inoperabilidade da cláusula da imprevisão, a que toda prisão cautelar deve ser submetida, com vistas a sujeitar sua permanência à presença efetiva dos motivos que a ensejaram. Quando a motivação é baseada em fatos ligados à pessoa do acusado (periculosidade, por exemplo) e não à conduta por ele praticada, as chances da prisão se prolongar por todo o processo são exponencialmente aumentadas, sobretudo porque elementos intrínsecos à pessoa do agente o acompanham indefinidamente. Além disso, "periculosidade" é critério para imposição de medida de segurança e, aqui, não há nada que ateste esse "perigo", tal como se faz com os doentes mentais. A constatação é meramente verificacionista (a partir de um relatório policial de investigação, por exemplo). Não há um laudo pericial atestando essa "periculosidade" por razões físicas/mentais, cuja alteração possa ser aferida por método equivalente, diante do que, essa evidência se transforma em verdade intocável e se perpetua, não cedendo espaço para rediscussão.

A análise da periculosidade do agente, realizada na grande maioria dos julgados consultados nesta pesquisa, permite que se estabeleça um paralelo quanto à seletividade do público-alvo dessas contenções cautelares, que ocorre desde o momento em que se elegem os crimes que oferecem maior perigo para a sociedade, os quais por suas especificidades, facilitam a fundamentação do encarceramento prévio. Aliás, a partir do momento em que o Brasil, assim como grande parte dos países latino-americanos, aderiu à ideia norte-americana de declarar "guerra às drogas", os delitos relativos a entorpecentes foram alçados a uma periculosidade generalizada, que, para fins de prisão, pouco diferencia o seu exercício em escalões altos ou baixos, gerando um aumento no encarceramento em níveis absurdos, além de permitir a punição de usuários, sob o pretexto de proteger a saúde pública ${ }^{58}$. Desse modo, invocar a periculosidade do investigado/acusado como pretexto para se prender preventivamente é sempre

\footnotetext{
${ }^{58}$ Para uma crítica da Saúde Pública como objeto de tutela do Estado pela via do Direito Penal, ver: CHAVES JUNIOR, Airto. Proteção penal da saúde pública no Brasil: duas críticas. Anais do I Encontro Virtual do CONPEDI. Direito Penal, Processo Penal e Constituição II. Florianópolis: CONPEDI, 2020, p. 60-80.
} 
CHAVES JUNIOR, Airto; SILVA, Luciana Bittencourt Gomes. Garantia da ordem pública como critério de encarceramento cautelar nas câmaras criminais do Tribunal de Justiça do Estado de Santa Catarina: uma análise teórico-empírica. Revista Eletrônica Direito e Política, Programa de Pós-Graduação Stricto Sensu em Ciência Jurídica da UNIVALI, Itajaí, v.15, n.3, 30 quadrimestre de 2020. Disponível em: www.univali.br/direitoepolitica - ISSN 1980-7791

um expediente que propicia o autoritarismo, eis que tal invocação é frequentemente fundada em pensamentos estereotipados acerca desse agente ${ }^{59}$.

\subsection{Prisão como garantia da ordem pública pelo merecimento da "sanção"}

A terceira possibilidade de prisão como garantia da ordem pública, bastante exercitada pelo TJSC, mas também enrustida, é a justificativa do merecimento, em que se utiliza a medida cautelar como verdadeira antecipação da pena com base num (pre) juízo de culpabilidade já enraizado na percepção do julgador. E aqui se opera uma fatal confusão entre os fins das medidas cautelares e os fins da pena de prisão, pois se incrementa a indevida importação de todas aquelas finalidades da pena (retribuição, prevenção, etc.) para dentro do processo. ${ }^{60}$ Aliás, aqui fica evidente que o caráter retributivo da pena, que não é capaz de justificar com suficiência nem mesmo as sanções definitivas, migrou para a prisão preventiva e nela encontrou morada definitiva como um instrumento autoritário de contenção, avalizado pelo Poder Judiciário. ${ }^{61}$

Em processos já sentenciados ou com a instrução concluída, verificou-se uma grande incidência da manutenção da prisão preventiva em razão de o réu ter "permanecido preso durante todo o processo", argumento que figurou em $55,79 \%$ dos acórdãos referentes a processos já sentenciados na origem (Gráfico $5)$.

\footnotetext{
59 FRAGOSO, Christiano Falk. Autoritarismo e Sistema Penal. p. 329.

60 Atualmente, no Brasil, é muito comum se ouvir tão logo se decreta uma prisão preventiva: "até que enfim, ele vai pagar pelo que fez".

${ }^{61}$ Conclusão confirmada por Gustavo Badaró, que anota que a prisão decretada sob o fundamento da garantia da ordem pública, em regra, acaba por se caracterizar em uma execução penal antecipada". (BADARÓ, Gustavo Henrique. Processo Penal. p. 977).
} 
CHAVES JUNIOR, Airto; SILVA, Luciana Bittencourt Gomes. Garantia da ordem pública como critério de encarceramento cautelar nas câmaras criminais do Tribunal de Justiça do Estado de Santa Catarina: uma análise teórico-empírica. Revista Eletrônica Direito e Política, Programa de Pós-Graduação Stricto Sensu em Ciência Jurídica da UNIVALI, Itajaí, v.15, n.3, $3^{\circ}$ quadrimestre de 2020. Disponível em: www.univali.br/direitoepolitica - ISSN 1980-7791

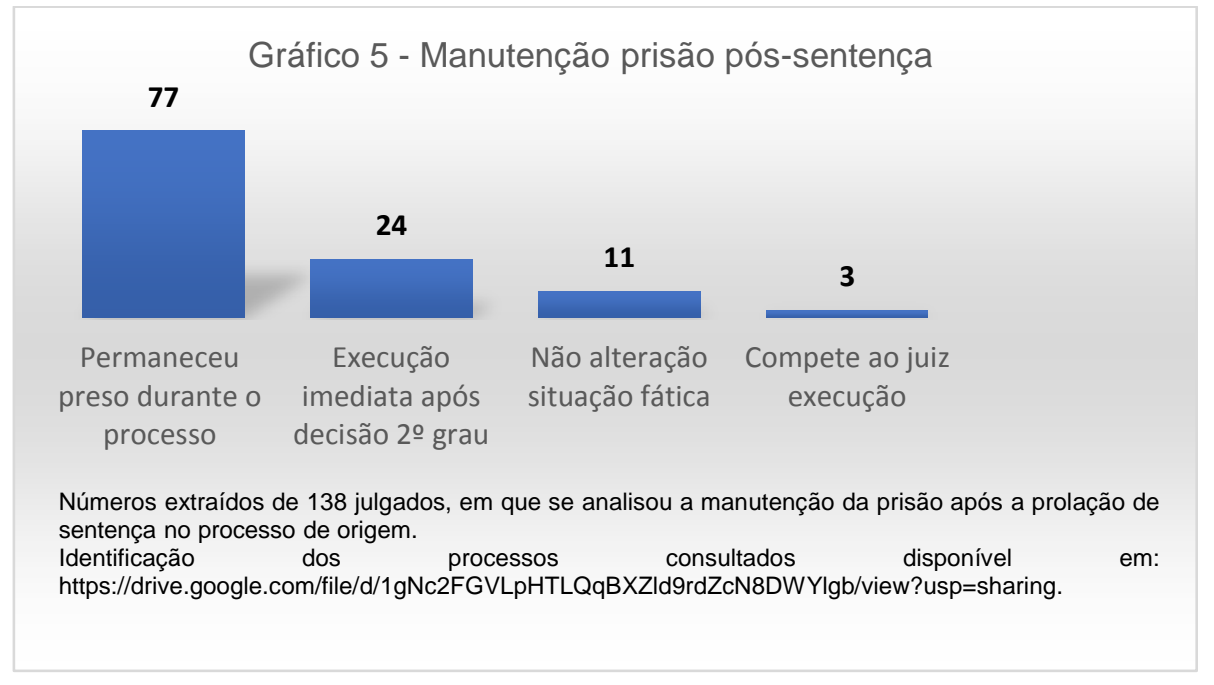

Evidencia-se, assim, a existência de um direito penal de prevenção, que franqueia a manifestação do poder punitivo por meio das contenções cautelares, satisfazendo o efeito simbólico de proteção da sociedade com a neutralização e afastamento de quem não se quer por perto. Nesses casos, incide a justificativa do merecimento de uma sanção que ainda não existe no plano definitivo. ${ }^{62}$

Sabe-se, porém, que a prisão preventiva (assim como qualquer outra medida cautelar) não se destina a "fazer justiça" nem tem relação alguma com "merecimento" (pagamento), mas sim garantir o normal funcionamento da justiça através do respectivo processo (penal) de conhecimento. Não tem eficácia material, pelo que, não pode ser empregada como sanção penal, pois é instrumento a serviço do processo. ${ }^{63} \mathrm{E}$, embora isso pareça figurar num plano bastante óbvio, é tanto melhor que esteja explicitado no âmbito da norma, o que é feito hoje ${ }^{64}$, a partir da previsão do art. $313, \S 20$, do Código de Processo

\footnotetext{
62 "Assim, tendo o apelante respondido todo o processo segregado, com posterior condenação, sem nenhuma alteração fática que tenha alterado à gravidade concreto do crime, bem como a garantia da ordem pública, a revogação da prisão preventiva se mostra inapropriada." (ACr. 000420352.2017.8.24.0135); "Réu, ademais, que permaneceu preso durante toda a instrução. Constrição preservada." (ACr. 0004199-35.2018.8.24.0020). (Sem grifos no original).

${ }^{63}$ Aqui, Aury Lopes Junior anota que a prisão preventiva deixa de ser instrumento cautelar quanto se afasta de seu objeto e de suas finalidades. (LOPES JUNIOR, Aury. Direito Processual Penal, p. 566-567).

${ }^{64}$ Diz-se, hoje, porque essa previsão passou a vigorar apenas em janeiro de 2020, com a edição da Lei 13.964/2019.
} 
CHAVES JUNIOR, Airto; SILVA, Luciana Bittencourt Gomes. Garantia da ordem pública como critério de encarceramento cautelar nas câmaras criminais do Tribunal de Justiça do Estado de Santa Catarina: uma análise teórico-empírica. Revista Eletrônica Direito e Política, Programa de Pós-Graduação Stricto Sensu em Ciência Jurídica da UNIVALI, Itajaí, v.15, n.3, $3^{\circ}$ quadrimestre de 2020. Disponível em: www.univali.br/direitoepolitica - ISSN 1980-7791

Penal, que passou a vedar a prisão preventiva para o fim de antecipação do cumprimento de pena. ${ }^{65}$

\subsection{Prisão como garantia da ordem pública em razão da suposta futura reiteração da conduta delitiva}

Espécie de "prisão de segurança", a quarta justificativa estampada na pesquisa é a de evitar uma provável "reiteração da conduta delitiva" 66 , mencionada em 260 dos acórdãos (equivalente a 48,87\% das decisões que decretaram ou mantiveram a prisão preventiva) (Gráfico 6).

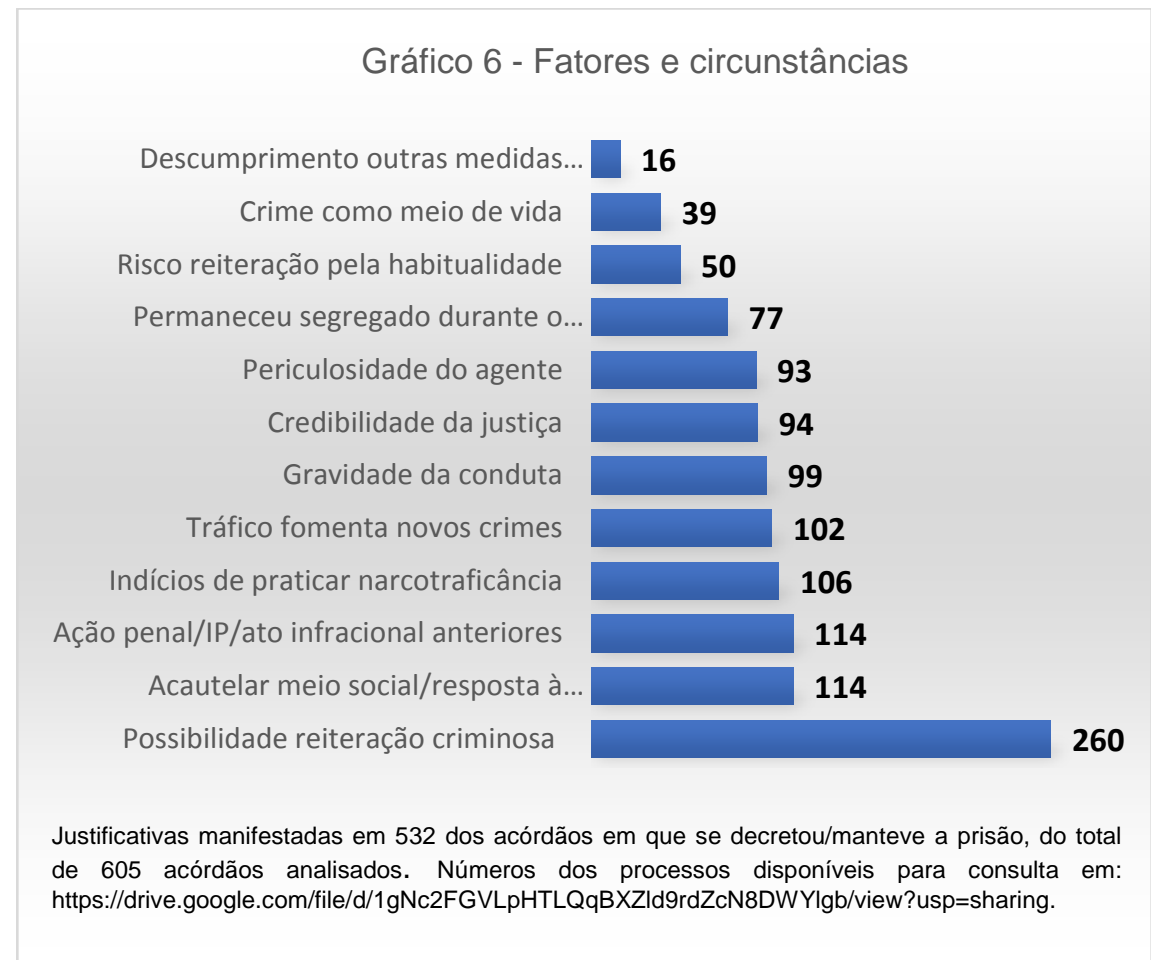

65 Código de Processo Penal, art. 313, § 20: "Não será admitida a decretação da prisão preventiva com a finalidade de antecipação de cumprimento de pena ou como decorrência imediata de investigação criminal ou da apresentação ou recebimento de denúncia".

66 Atualmente, na Alemanha, não se utiliza a expressão "garantia da ordem pública", mas um conceito mais restrito, porém semelhante: "perigo de repetição" (Wiederholungsgefahr). Conforme Claus Roxin, isso teve início em 1964, quando a prisão pelo perigo de reiteração delitiva foi introduzida para determinados delitos sexuais que, conforme a experiência prática, muitas das vezes são cometidos como delitos em série. (ROXIN, Claus. Derecho Procesal Penal. p. 261). 
CHAVES JUNIOR, Airto; SILVA, Luciana Bittencourt Gomes. Garantia da ordem pública como critério de encarceramento cautelar nas câmaras criminais do Tribunal de Justiça do Estado de Santa Catarina: uma análise teórico-empírica. Revista Eletrônica Direito e Política, Programa de Pós-Graduação Stricto Sensu em Ciência Jurídica da UNIVALI, Itajaí, v.15, n.3, $3^{\circ}$ quadrimestre de 2020. Disponível em: www.univali.br/direitoepolitica - ISSN 1980-7791

A esse fator, somam-se as alusões, feitas em mais 50 julgados, ao risco da reiteração criminosa pela habitualidade da conduta, em vários dos casos, presumido pelo caráter lucrativo do tráfico. ${ }^{67}$

Na mesma linha de uso da prisão para barrar atividades criminosas futuras, o uso da expressão "fazer do crime meio de vida" reforçou a fundamentação para a decretação de 39 contenções, evidenciando-se mais uma especificidade do crime de tráfico de drogas que conduz à prisão. ${ }^{68}$

Novamente, não se trata de um caso de asseguramento do processo, mas de uma detenção por segurança imposta por uma suspeita não provada, tanto no que diz respeito ao fato punível cometido quanto ao que ainda se espera que seja cometido" 69 . Com esse fundamento, a prisão preventiva assume a fisionomia de atividade tipicamente de polícia ${ }^{70}$, utilizada indevidamente como medida de segurança pública e tutela coletiva ${ }^{71}$, e é justamente neste cenário que se possibilita o exercício arbitrário das prisões.

\footnotetext{
67 "Situação a indicar habitualidade e risco concreto de reiteração. Efetiva necessidade de acautelar o meio social." (HC 4021959-52.2019.8.24.0000); "Portanto, considerando [...] a natureza do crime em voga (hediondo), que, por si só, culmina em um juízo de probabilidade de reiteração delitiva (especialmente em razão do lucro gerado pelo narcotráfico), [...] tenho por demonstrado, indene de dúvidas, a imprescindibilidade do resguardo da ordem pública e da aplicação da lei penal por meio da segregação preventiva em segunda instância." (ACr. 0001096-45.2018.8.24.0044). (Sem grifos no original).

68 "A garantia da ordem pública está respaldada no fato de que, caso posto em liberdade, o paciente colocará em risco a tranquilidade do meio social, uma vez que sobre ele recaem indícios de que se valia da prática de delitos como um de seus meios de vida e, caso retorne às ruas, reiterará tais condutas." (HC 4025231-54.2019.8.24.0000); "Logo, diante de tais argumentos [...] - não há falar em inexistência de risco concreto à ordem pública, porquanto evidenciada a habitualidade da conduta, fazendo, em tese, do comércio odioso seu modo de vida, considerando que não trabalha. É sabido que não trabalhar não é razão para qualquer modalidade de cerceamento da liberdade. Entretanto, sem atividade lícita e operando com narcóticos, resta claro que haverá reiteração delituosa e demonstra a periculosidade do agente." (HC 403019153.2019.8.24.0000). (Sem grifos no original).
}

69 ROXIN, Claus. Derecho Procesal Penal. p. 261-262.

70 LOPES JUNIOR, Aury. Direito Processual Penal. p. 567.

${ }^{71}$ Acerca da evolução italiana a respeito do tema, ver: FERRAJOLI, Luigi. Direito e Razão: teoria do garantismo penal. p. 444-445. 
CHAVES JUNIOR, Airto; SILVA, Luciana Bittencourt Gomes. Garantia da ordem pública como critério de encarceramento cautelar nas câmaras criminais do Tribunal de Justiça do Estado de Santa Catarina: uma análise teórico-empírica. Revista Eletrônica Direito e Política, Programa de Pós-Graduação Stricto Sensu em Ciência Jurídica da UNIVALI, Itajaí, v.15, n.3, $3^{\circ}$ quadrimestre de 2020. Disponível em: www.univali.br/direitoepolitica - ISSN 1980-7791

\subsection{Prisão como garantia da ordem pública para assegurar a credibilidade da Justiça}

Uma quinta possibilidade em que encarcera provisoriamente sob a justificativa de garantir a ordem pública, verificada nos acórdãos pesquisados, cada vez mais utilizada no âmbito do processo é a prisão como meio de "assegurar a credibilidade da justiça". Conforme anota Aury Lopes Junior ${ }^{72}$, a restrição da liberdade do investigado ou acusado, nestes termos, "seria um antídoto para a omissão do Poder Judiciário, Polícia e Ministério Público" servindo, indevidamente "para reafirmar a 'crença' no aparelho estatal repressor".

De acordo com a pesquisa, esse expediente foi utilizado em 94 julgados (Gráfico 6), correspondente a $21,96 \%$ dos casos de decretação/manutenção da prisão com base na garantia da ordem pública. ${ }^{73}$ Esse fundamento é rotineiramente invocado para se prender alguém em casos de repercussão midiática. No entanto, além de ser um argumento apócrifo, não confere credibilidade à Justiça; pelo contrário, promove o autoritarismo para se fazer crer que a Justiça é alcançada por meio do cárcere.

\section{UM ADENDO, (A)FINAL}

A partir do emprego maciço dessas cinco justificativas flagrantemente dissociadas das finalidades da medida cautelar, revela-se que a grande maioria das prisões preventivas decretadas ou mantidas pelo Tribunal de Justiça do Estado de Santa Catarina escapam a evidência concreta da ocorrência dos dois

\footnotetext{
72 LOPES JUNIOR, Aury. Direito Processual Penal. p. 556

73 "No que atine à imperiosidade da clausura cautelar, as circunstâncias que permeiam a conjuntura em apreço - realização do comércio espúrio em região conhecida por tal prática denotam que a sua liberdade representa nítido risco à paz social, sendo certo que a proteção da coletividade e a credibilidade da Justiça também devem ser consideradas." (RESE 000662574.2019.8.24.0023); "Desse modo, considerando que a prisão preventiva, in casu, possui o condão de preservar a ordem social e de garantir a ordem pública, assim como a credibilidade da Justiça, bem como evitar a reiteração criminosa, ficam plenamente preenchidas as exigências legais da referida medida, evidenciando-se sua necessidade." (HC 4025084-28.2019.8.24.0000); "Assim, entende-se que as circunstâncias do caso concreto são suficientes à demonstração da necessidade de manutenção da segregação cautelar, que visa também acautelar o meio social e a própria credibilidade da Justiça." (HC 4025513-92.2019.8.24.0000). (Sem grifos no original).
} 
CHAVES JUNIOR, Airto; SILVA, Luciana Bittencourt Gomes. Garantia da ordem pública como critério de encarceramento cautelar nas câmaras criminais do Tribunal de Justiça do Estado de Santa Catarina: uma análise teórico-empírica. Revista Eletrônica Direito e Política, Programa de Pós-Graduação Stricto Sensu em Ciência Jurídica da UNIVALI, Itajaí, v.15, n.3, 30 quadrimestre de 2020. Disponível em: www.univali.br/direitoepolitica - ISSN 1980-7791

pressupostos efetivamente cautelares do periculum libertatis: conveniência da instrução criminal e assegurar a aplicação da lei penal. ${ }^{74}$

E diante da inexistência de fatos concretos que levem a concluir que o acusado efetivamente irá prejudicar a investigação ou a instrução do processo, ou diante da ausência de indicativos seguros de uma real tentativa de fuga, que o levaria a se eximir de cumprir uma pena aplicada em suposta futura sentença condenatória, a fundamentação da prisão para garantia da ordem pública se apresenta como um método eficaz para manter o acusado preso durante todo o processo, conforme se verifica nas decisões em que, afastados os demais fundamentos, a garantia da ordem pública permanece a sustentar a prisão (ver, a título aproximativo, o Gráfico 4).

Lembram Claus Roxin e Bernd Schünemann que "o processo penal é o sismógrafo da Constituição". No plano dos Direitos Fundamentais, fala-se numa "regra constitucional ôntica da liberdade". Desse modo, a possibilidade de o Estado privar alguém do exercício desse direito deve guardar absoluto respeito às cláusulas constitucionais e legais de restrição. A liberdade é um direito inato do ser humano e, por isso, regra. De outra parte, a prisão cautelar é entidade criada pelo aparelho regulamentador estatal para fins específicos e, nesta perspectiva, exceção.

Neste campo de exercício de direitos e possibilidades de limitações a esses direitos, regulam-se os complexos embates entre a autoridade pública que exerce o poder de encarcerar e o particular que tem suportado essas manifestações do exercício do poder punitivo. Por isso, para fazer valer o direito à liberdade, não se pode abandonar a acepção sustentada por Luigi Ferrajoli ${ }^{75}$ de que a lei deve se afirmar como protetora do mais fraco em situação de contraposição ao mais forte; de que o Processo Penal é instrumento de garantia para o acusado, instrumento de proteção de excessos e abusos do Estado.

\footnotetext{
${ }^{74}$ A prisão preventiva decretada sob um desses dois pressupostos fáticos deve trazer, em seu fundamento, o fato claro e determinado a partir do qual se pode concluir que se busca acautelar o processo penal com essa prisão. Não se admite, pois, "ilações ou criações fantasmagóricas de fuga (ou de qualquer dos outros perigos)" (LOPES JUNIOR, Aury. Direito Processual Penal. p. 558).
}

${ }^{75}$ FERRAJOLI, Luigi. Democracia y Garantismo. p. 36. 
CHAVES JUNIOR, Airto; SILVA, Luciana Bittencourt Gomes. Garantia da ordem pública como critério de encarceramento cautelar nas câmaras criminais do Tribunal de Justiça do Estado de Santa Catarina: uma análise teórico-empírica. Revista Eletrônica Direito e Política, Programa de Pós-Graduação Stricto Sensu em Ciência Jurídica da UNIVALI, Itajaí, v.15, n.3, 30 quadrimestre de 2020. Disponível em: www.univali.br/direitoepolitica - ISSN 1980-7791

Porém, conforme se verifica dos números trazidos na pesquisa, a função da prisão preventiva é deslocada de sua previsão inicial (tutela do processo) para se transformar em aparência de segurança pública, sempre com o proveito da anemia semântica da expressão "ordem pública". De acordo com os dados registrados, fica mais fácil compreender o que se esconde entre os fundamentos legais e a disposição dos agentes que atuam no processo, quase que sempre a partir de argumentos retóricos banhados de frases feitas do tipo "segurança coletiva", "escalada da criminalidade", ${ }^{76}$ dentre outras situações criadas a la carte.

Desse modo, por meio da aplicação da lei se permite a violação velada dos limites necessários à própria existência do Estado e à manutenção da Democracia, tudo a partir da operacionalidade de um sistema normativo paralelo ou, de outro modo, na configuração daquilo que Giorgio Agamben ${ }^{77}$ denomina de estado de exceção. O discurso de que há um estado permanente de medo e de criminalidade "além dos limites aceitáveis" incrementa, voluntariamente, um estado de emergência permanente (mesmo que isso não seja assim declarado). Opera-se, aqui, um mecanismo de crenças dos agentes processuais que se convencem que quaisquer dessas cinco "razões" estampadas na pesquisa justificariam a prisão, pelo que, seria um alvo a se buscar. Dito de outro modo, os motivos são tão fluidos que é possível, a partir deles, invocar-se qualquer argumento para se prender alguém.

Não se pode deixar escapar, por fim, o efeito mediato dessa operacionalidade marginal à lei: os casos de investigados/acusados presos preventivamente revelam uma resistência flagrante em se absolver, de modo que só se decide favoravelmente ao preso quando o julgador não encontra nenhuma possibilidade de condenação ${ }^{78}$, numa evidente inversão de sinais e violação à presunção de inocência. ${ }^{79}$

\footnotetext{
${ }^{76}$ ROSA, Alexandre Morais da. Guia do Processo Penal conforme a Teoria dos Jogos. p. 460.

77 AGAMBEN, Giorgio. Estado de excepção. p. 13.

78 ZAFFARONI, Eugenio Raúl. 0 inimigo no direito penal. p. 71.

${ }^{79}$ Esse fenômeno talvez possa ser explicado pela Teoria da Dissonância Cognitiva. Sobre o tema, ver: SCHÜNEMANN, Bernd. O juiz como um terceiro manipulado no processo penal? Uma confirmação empírica dos efeitos perseverança e correspondência comportamental. Revista
} 
CHAVES JUNIOR, Airto; SILVA, Luciana Bittencourt Gomes. Garantia da ordem pública como critério de encarceramento cautelar nas câmaras criminais do Tribunal de Justiça do Estado de Santa Catarina: uma análise teórico-empírica. Revista Eletrônica Direito e Política, Programa de Pós-Graduação Stricto Sensu em Ciência Jurídica da UNIVALI, Itajaí, v.15, n.3, 30 quadrimestre de 2020. Disponível em: www.univali.br/direitoepolitica - ISSN 1980-7791

\section{CONSIDERAÇÕES FINAIS}

Os índices divulgados no banco de dados INFOPEN e no Banco Nacional de Monitoramento de Prisões apontam para a ocorrência de um número excessivo de prisões provisórias no Brasil. No entanto, essas estatísticas não abordam as razões pelas quais tantas prisões se concretizam, o que motivou 0 desenvolvimento da presente pesquisa.

$\mathrm{Na}$ coleta de dados, foram pesquisados 605 (seiscentos e cinco) acórdãos lavrados pelas 5 Câmaras Criminais do Tribunal de Justiça Catarinense no período de 01/07/2019 a 01/07/2020, que analisaram a necessidade da manutenção/decretação das prisões preventivas dos investigados/acusados, levados a exame no segundo grau de jurisdição e que cuidam de processos relacionados ao crime de tráfico de drogas.

Dessa análise, verificou-se que as prisões preventivas foram mantidas ou decretadas, em quase sua totalidade, sob a justificativa de se garantir a ordem pública. A alta incidência dessa fundamentação, que atingiu o patamar de $99,53 \%{ }^{80}$ nos casos em que se viu conjugada com os demais fundamentos do art. 312 do CPP (conveniência da instrução criminal ou garantia da aplicação da lei penal), permite afirmar que a garantia da ordem pública constitui, atualmente, a fundamentação-padrão das prisões preventivas nas Câmaras Criminais do TJSC.

A confirmação dessa hipótese foi reforçada com a constatação do insignificante número de decisões em que os fundamentos da conveniência da instrução criminal e da garantia da aplicação da lei penal figuraram isoladamente nos julgados, tendo a primeira embasado a necessidade da prisão em apenas 1 (um) julgado e a fundamentação exclusiva para garantir a aplicação da lei penal não foi constatada em nenhum dos casos pesquisados no período. Em contrapartida,

Liberdades: Publicação Oficial do Instituto Brasileiro de Ciências Criminais. São Paulo, no 11 , set./dez. $2012 . \quad$ Disponível em: http://revistaliberdades.org.br/site/outrasEdicoes/outrasEdicoesExibir.php?rcon_id=140. Acesso em: 10 out. 2020.

${ }^{80}$ Porcentagem extraída dos 430 acórdãos em que as prisões foram decretadas ou mantidas com fundamento expresso no art. 312 do CPP, em que houve conjugação de justificações. 
CHAVES JUNIOR, Airto; SILVA, Luciana Bittencourt Gomes. Garantia da ordem pública como critério de encarceramento cautelar nas câmaras criminais do Tribunal de Justiça do Estado de Santa Catarina: uma análise teórico-empírica. Revista Eletrônica Direito e Política, Programa de Pós-Graduação Stricto Sensu em Ciência Jurídica da UNIVALI, Itajaí, v.15, n.3, $3^{\circ}$ quadrimestre de 2020. Disponível em: www.univali.br/direitoepolitica - ISSN 1980-7791

a garantia da ordem pública, em $86,79 \%{ }^{81}$ dos votos, sustentou exclusivamente a prisão, e em várias oportunidades, substituiu os demais fundamentos, quando seus indícios não mais subsistiam no caso sob apreciação.

Partindo dessas informações, passou-se a investigar os fatores que possibilitaram o uso dessa motivação em larga escala, inferindo-se que sua alta incidência resultou como efeito de uma interpretação inadequada do embasamento legal e conceitual das prisões preventivas. Feita a abordagem da dimensão teórica do instituto, com a exposição das suas finalidades e critérios, restou claro que seu uso, em conformidade com a norma e com a teoria, não permitiria tal resultado.

Da análise dos acórdãos, constatou-se a presença de vários fundamentos apócrifos - não previstos na lei. Esses fundamentos sustentaram as prisões para garantia da ordem pública em percentuais bastante elevados, muitas vezes combinados (cumulados) e não excludentes. Dos números, destacaram-se cinco deles, quais sejam:

a) intranquilidade coletiva no seio da comunidade - constatada em 216 julgados $^{82}$;

b) características ligadas ao sujeito ou à execução do delito, mencionadas em 205 acórdãos ${ }^{83}$;

c) merecimento, verificada em 77 acórdãos exarados em processos já sentenciados na origem ou com instrução já concluída;

d) suposta reiteração da conduta delitiva, constante em 260 decisões; e,

\footnotetext{
${ }^{81}$ Percentual referente ao total de 430 acórdãos em que as prisões foram decretadas ou mantidas com fundamento expresso nos incisos do artigo 312 do CPP, sob a análise de fundamentação exclusiva para cada inciso.

82 Destes, em 114 foram utilizados termos como "a liberdade causa temor", "proteção da coletividade" ou "prisão para acautelar o meio social", e equivalentes, e em mais 102, por meio da regra de que o tráfico "fomenta a prática de outros crimes", admitiu-se a prisão para afastar o perigo do crime da coletividade.

83 Consistente na soma dos 99 acórdãos que mencionam a suposta gravidade da conduta, ligada à periculosidade social do agente, aos 106 que fazem referência a expressões relativas à própria adequação típica, como "foram localizados petrechos comumente utilizados na atividade ilícita", "há notícia de que o paciente se dedicava ao tráfico de drogas, como entregador", "há fortes indícios de que a droga era destinada à venda", ou a simples alusão a "indícios de que pratica a narcotraficância".
} 
CHAVES JUNIOR, Airto; SILVA, Luciana Bittencourt Gomes. Garantia da ordem pública como critério de encarceramento cautelar nas câmaras criminais do Tribunal de Justiça do Estado de Santa Catarina: uma análise teórico-empírica. Revista Eletrônica Direito e Política, Programa de Pós-Graduação Stricto Sensu em Ciência Jurídica da UNIVALI, Itajaí, v.15, n.3, 30 quadrimestre de 2020. Disponível em: www.univali.br/direitoepolitica - ISSN 1980-7791

e) credibilidade da justiça, que fundamentou a prisão em 94 julgados.

Nesse ponto, foi possível concluir que a indeterminação e a vagueza do termo "garantia da ordem pública" possibilitam que, sob o argumento de seu resguardo, sejam sustentadas prisões preventivas fora da lei (sem amparo legal), sobretudo, porque alheias à situação de cautelaridade processual, em plena dissonância com o aporte legislativo e teórico que orienta o tema.

\section{REFERÊNCIAS DAS FONTES CITADAS}

ALEXY, Robert. Teoria dos Direitos Fundamentais. Tradução de Vergílio Afonso da Silva. São Paulo: Malheiros, 2008.

AVEnA, Norberto. Processo Penal. Rio de Janeiro: Forense, 2019.

ABBAGNANO, Nicola. Dicionário de Filosofia. Tradução de Alfredo Bossi. 5. ed. São Paulo: Martins Fontes, 2007.

AGAMBEN, Giorgio. Estado de excepção. Tradução de Miguel Freitas da Costa. Lisboa/Porto: Edições 70. São Paulo: Boitempo, 2010.

BADARÓ, Gustavo Henrique. Processo Penal. São Paulo: Revista dos Tribunais, 2015.

BRASIL. Constituição (1988). Constituição da República Federativa do Brasil. Brasília, DF: Senado Federal, 1988.

BRASIL. Ministério da Justiça. Levantamento Nacional de Informações Penitenciárias 2019 - INFOPEN. Brasília, 2019. Disponível em: https://app.powerbi.com/view?r=eyJrIjoiZWI2MmJmMzYtODA2MC00YmZiLWI4M 2ItNDU2ZmIyZjFjZGQ0IiwidCI6ImViMDkwNDIwLTQ0NGMtNDNmNy05MWYyLTRi OGRhNmJmZThIMSJ9. Acesso em: 20 jul 2020.

CANOTILHO, J.J. Gomes. Direito Constitucional e Teoria da Constituição. 7. ed. Coimbra: Almeidina, 2003.

CHARON, Joel. Sociologia. Tradução de Laura Teixeira Motta. São Paulo, 1999.

CHAVES JUNIOR, Airto. Proteção penal da saúde pública no Brasil: duas críticas. Anais do I Encontro Virtual do CONPEDI. Direito Penal, Processo Penal e Constituição II. Florianópolis: CONPEDI, 2020.

CHAVES JUNIOR, Airto; OLDONI, Fabiano. Para que(m) serve o Direito Penal? Uma análise criminológica dos segmentos de controle social. Rio de Janeiro: Lumen Juris, 2014. 
CHAVES JUNIOR, Airto; SILVA, Luciana Bittencourt Gomes. Garantia da ordem pública como critério de encarceramento cautelar nas câmaras criminais do Tribunal de Justiça do Estado de Santa Catarina: uma análise teórico-empírica. Revista Eletrônica Direito e Política, Programa de Pós-Graduação Stricto Sensu em Ciência Jurídica da UNIVALI, Itajaí, v.15, n.3, 30 quadrimestre de 2020. Disponível em: www.univali.br/direitoepolitica - ISSN 1980-7791

CONSELHO NACIONAL DE JUSTIÇA. Banco Nacional de Monitoramento de Prisões - BNMP. Brasília, 2020. Disponível em: https://portalbnmp.cnj.jus.br/\#/estatisticas. Acesso em: 27 jul 2020.

FERRAJOLI, Luigi. Democracia y Garantismo. Tradução de Perfecto Andrés Ibáñez e outros. Madri: Trotta, 2008.

FERRAJOLI, Luigi. Derechos y garantias. 3. ed. Madrid: Trotta, 2002.

FERRAJOLI, Luigi. Direito e Razão: teoria do garantismo penal. Tradução de Ana Paula Zomer e outros. São Paulo: Revista dos Tribunais, 2002.

FERRAJOLI, Luigi. Principia iuris: teoria del derecho y de la democracia. Madrid: Trotta, 2007.

FRAGOSO, Christiano Falk. Autoritarismo e Sistema Penal. Rio de Janeiro: Lumen Juris, 2015.

GARCIA, Basileu. Comentários ao Código de Processo Penal. Rio de Janeiro: Forense, 1945.

GELLATELY, Robert. Apoiando Hitler: consentimento e coerção na Alemanha nazista. Tradução de Vitor Paolozzi. Rio de Janeiro: Editora Record, 2011.

LOPES JUNIOR, Aury. Direito Processual Penal. 13. ed. São Paulo: Saraiva, 2016 (Versão digital).

OliveirA, Eugênio Pacelli de. Curso de Processo Penal. 19. ed. São Paulo: Atlas, 2015.

NUCCI, Guilherme de Souza. Manual de processo penal e execução penal. 5. ed. São Paulo: Revista dos Tribunais, 2008.

ROSA, Alexandre Morais da. Guia do Processo Penal conforme a Teoria dos Jogos. 6. ed. Florianópolis: EMais, 2020.

ROXIN, Claus. Derecho Procesal Penal. Tradução de Gabriela Córdoda y Daniel Pastor. Buenos Aires: Editores del Puerto, 2003.

SARLET, Ingo Wolfgang. A constituição concretizada. Porto Alegre: Livraria do Advogado, 2000.

SARLET, Ingo Wolfgang; MARINONI, Luis Guilherme; MITIDIERO Daniel (Org.). Curso de Direito Constitucional. 6. ed. São Paulo: Saraiva, 2017 (versão digital).

SCHÜNEMANN, Bernd. O juiz como um terceiro manipulado no processo penal? Uma confirmação empírica dos efeitos perseverança e correspondência comportamental. Revista Liberdades: Publicação Oficial do Instituto Brasileiro de Ciências Criminais. São Paulo, no 11, set./dez. 2012. Disponível em: 
CHAVES JUNIOR, Airto; SILVA, Luciana Bittencourt Gomes. Garantia da ordem pública como critério de encarceramento cautelar nas câmaras criminais do Tribunal de Justiça do Estado de Santa Catarina: uma análise teórico-empírica. Revista Eletrônica Direito e Política, Programa de Pós-Graduação Stricto Sensu em Ciência Jurídica da UNIVALI, Itajaí, v.15, n.3, 30 quadrimestre de 2020. Disponível em: www.univali.br/direitoepolitica - ISSN 1980-7791

http://revistaliberdades.org.br/site/outrasEdicoes/outrasEdicoesExibir.php?rcon_i $\mathrm{d}=140$. Acesso em: 10 out. 2020.

SILVA, José Afonso da. Aplicabilidade das Normas Constitucionais. 3. ed. rev. ampl. atual. São Paulo: Malheiros Editores, 1998.

SILVA, José Afonso da. Teoria do Conhecimento Constitucional. São Paulo: Malheiros, 2014.

STEINER, Sílvia. A convenção americana sobre direitos humanos e sua integração ao processo penal brasileiro. São Paulo: Revista dos Tribunais, 2000.

TRIBUNAL DE JUSTIÇA DE SANTA CATARINA. Jurisprudência catarinense. Disponível em: http://busca.tjsc.jus.br/jurisprudencia/\#formulario_ancora. Acesso em: 10 jul 2020.

ZAFFARONI, Eugenio Raúl. O inimigo no direito penal. Tradução de Sérgio Lamarão. 3. ed. Rio de Janeiro: Revan, 2019. 